and aliphatic $\mathrm{C}=\mathrm{C} /$ heterocyclic $\mathrm{C}-\mathrm{N} /$ aromatic $\mathrm{C}=\mathrm{C}$ [23]. Furthermore, $\mathrm{SO}_{2}$ can lead to degradation of solid amine adsorbents by forming sulfate $[17,22,44]$, sulfite $[17,22$, 44, 45], bisulfite (under humid conditions) [45], and even nitro- and quinone-type compounds (aromatic amine) [22]. $\mathrm{NO}_{2}$ can result in degradation of solid amine adsorbents by forming nitrate and nitro-compounds $[46,47]$. Although it has been reported that NO has no apparent adverse effects on solid amine sorbents $[27,31,44,46,48$, 49], a few researchers found that NO can lead to the loss of $\mathrm{CO}_{2}$ adsorption capacity in solid amine sorbents $[28,50]$.

Overall, the degradation of solid amine adsorbents induced by $\mathrm{O}_{2}, \mathrm{SO}_{2}$, and $\mathrm{NO}_{x}$ has been investigated relatively comprehensively by past studies. However, there is still a lack of information on the degradation of PEl functional adsorbents when interacting with $\mathrm{O}_{2}, \mathrm{SO}_{2}$, and $\mathrm{NO}_{x^{\prime}}$ which is the focus of this study. BPEI and LPEI functional adsorbents were evaluated during long-term interactions with $\mathrm{O}_{2}, \mathrm{SO}_{2}$, and $\mathrm{NO}_{\mathrm{x}}$. Their degradation mechanisms were explored in more detail to clarify the degradation pathways of PEI molecules.

\section{Experimental work}

\subsection{Chemicals}

BPEI (molecular weight [MW] 25,000) and potassium bromide ( $\mathrm{KBr}$, IR grade) were purchased from Alfa Aesar (Tewksbury, MA, USA). LPEI (MW 25,000) was purchased from Polysciences (Warrington, PA, USA). The molecular structures of BPEI and LPEI are shown in Scheme S1 in the Supplementary Information. Methanol (HPLC grade) was purchased from Fisher Scientific (Waltham, MA, USA). Nano silica used as support was synthesized in lab, its surface area and pore volume respectively were $418 \mathrm{~m}^{2} / \mathrm{g}$ and $0.84 \mathrm{~cm}^{3} / \mathrm{g}$ [51]. All of the gases, including $99.999 \% \mathrm{~N}_{2}$, $15 \% \mathrm{CO}_{2}$ balanced with $\mathrm{N}_{2}, 15 \% \mathrm{CO}_{2}$ and $10 \% \mathrm{O}_{2}$ balanced with $\mathrm{N}_{2}, 15 \% \mathrm{CO}_{2}$ and 200 ppm NO balanced with $\mathrm{N}_{2}, 15 \%$ $\mathrm{CO}_{2}$ and 10 or 200 ppm NO 2 balanced with $\mathrm{N}_{2}, 15 \% \mathrm{CO}_{2}$ and 10,50 , or 200 ppm SO $\mathrm{S}_{2}$ balanced with $\mathrm{N}_{2}$, were provided by ZG Special Gases (Beijing, China).

\subsection{Preparation of PEl functional adsorbents}

First, BPEI or LPEI was dissolved into $25 \mathrm{ml}$ methanol and stirred for 30 min using a magnetic mixer. Second, $2 \mathrm{~g}$ nano-silica was added to the solution. The silica had been dried in an oven at $105^{\circ} \mathrm{C}$ under vacuum conditions $(<1 \mathrm{~mm} \mathrm{Hg}$ ) for $3 \mathrm{~h}$. Third, another $5 \mathrm{ml}$ methanol was added to the solution with stirring at ambient temperature until all of the methanol evaporated. Finally, the sample was dried at $50^{\circ} \mathrm{C}$ under vacuum conditions $(<1 \mathrm{~mm} \mathrm{Hg})$ for $2 \mathrm{~h}$. The products were named $\mathrm{BPEI}_{-} \mathrm{SiO}_{2}$ and $\mathrm{LPEI}-\mathrm{SiO}_{2}$.

\subsection{Characterizations}

$\mathrm{CO}_{2}$ cyclic adsorption-desorption tests were conducted using the TGA/DSC 2 thermogravimetric analyzer (Mettler Toledo, Greifensee, Switzerland). First, 15-20 mg adsorbents were placed into an aluminum oxide pan and pretreated at $120^{\circ} \mathrm{C}$ for 30 min under a $\mathrm{N}_{2}$ atmosphere. Second, the samples were cooled to $75^{\circ} \mathrm{C}$, and the $\mathrm{N}_{2}$ gas was substituted with gas $1\left(15 \% \mathrm{CO}_{2}\right.$ balanced with $\mathrm{N}_{2}$ ) for a 10-min adsorption period. The temperature was elevated, and gas 1 was switched to $\mathrm{N}_{2}$ for 10 min desorption at $120^{\circ} \mathrm{C}$. Third, the samples were cooled to $75^{\circ} \mathrm{C}$, and the gas was switched from $\mathrm{N}_{2}$ to gas $2\left(15 \% \mathrm{CO}_{2}\right.$ with some $\mathrm{O}_{2}, \mathrm{NO}, \mathrm{NO}_{2}$, or $\mathrm{SO}_{2}$ in $\mathrm{N}_{2}$ ) for 10 min adsorption. The temperature was elevated, and gas 2 was switched to $\mathrm{N}_{2}$ for 10 min desorption at $120^{\circ} \mathrm{C}$. Finally, the second and third steps were repeated 100 times. A reference test was also performed in which the second step was repeated 200 times. At the end of each test, the samples were stabilized for $2 \mathrm{~h}$ at $75^{\circ} \mathrm{C}$ under a $\mathrm{N}_{2}$ atmosphere. For the analysis, the $\mathrm{CO}_{2}$ adsorption capacity of the $1 \mathrm{st}, 3 \mathrm{rd}, 5 \mathrm{th}, \ldots$, and 199 th cycles were used. The samples used for cyclic adsorption-desorption tests under different conditions were denoted as $\mathrm{BPEI}-\mathrm{SiO}_{2}$ or $\mathrm{LPEI}-\mathrm{SiO}_{2}$, followed by the volumetric concentration of $\mathrm{CO}_{2}, \mathrm{O}_{2}, \mathrm{SO}_{2}$, or $\mathrm{NO}_{x}$ in brackets. For example, $\mathrm{BPEI}_{-} \mathrm{SiO}_{2}(200 \mathrm{ppm} \mathrm{NO})$ refers to $\mathrm{BPEI}_{-} \mathrm{SiO}_{2}$ samples exposed to $200 \mathrm{ppm} \mathrm{NO}\left(15 \% \mathrm{CO}_{2}\right.$ and $200 \mathrm{ppm}$ $\mathrm{NO}$ balanced with $\mathrm{N}_{2}$ ) in the adsorption-desorption cycles. BPEI-SiO ${ }_{2}\left(15 \% \mathrm{CO}_{2}\right)$ or LPEI-SiO $2\left(15 \% \mathrm{CO}_{2}\right)$ indicate that no $\mathrm{O}_{2}, \mathrm{SO}_{2}$, or $\mathrm{NO}_{x}$ was present during the adsorption-desorption tests.

Diffuse reflectance infrared Fourier transform (DRIFT) spectra for fresh adsorbents and samples from cyclic adsorption-desorption tests were collected by the Nicolet 6700 spectrometer coupled with an in situ reaction cell (Thermo Fisher Scientific, Waltham, MA, USA). The resolution and scan time were set as $4 \mathrm{~cm}^{-1}$ and 32 , respectively. The spectra were recorded in the range of $400-4000 \mathrm{~cm}^{-1}$. The spectrum of $\mathrm{KBr}$ under $\mathrm{N}_{2}$ was used as the background. In situ DRIFT spectra of $\mathrm{BPEI}_{-} \mathrm{SiO}_{2}$ and $\mathrm{LPEI}^{-\mathrm{SiO}_{2}}$ during interaction with different gas mixtures were also recorded using the Nicolet 6700 spectrometer. First, fresh samples of $\mathrm{BPEI}-\mathrm{SiO}_{2}$ and $\mathrm{LPEI}-\mathrm{SiO}_{2}$ were placed in the in situ reaction cell, the cell was sealed, and the sample was degassed for $2 \mathrm{~h}$ at $120^{\circ} \mathrm{C}$ under $\mathrm{N}_{2}$. The spectra were recorded and denoted as spectrum 1 . Second, the samples were cooled to $75^{\circ} \mathrm{C}$ under $\mathrm{N}_{2}$, and the spectra were collected and used as the background for recording the test spectra in the presence of gases 1 or 2 . Third, the $\mathrm{N}_{2}$ was switched to gas 1 or gas 2 , and simultaneously start to record infrared 
(IR) spectra at certain time points. Finally, after 10 or $24 \mathrm{~h}$ of interaction with gas 1 or gas 2, the temperature was increased and the atmosphere simultaneously switched to $\mathrm{N}_{2}$. Samples were regenerated at $120^{\circ} \mathrm{C}$ under $\mathrm{N}_{2}$ for $1 \mathrm{~h}$, and the IR spectra were recorded (using spectrum 1 as a background).

\section{Results and discussion}

\subsection{The adverse effects of $\mathrm{O}_{2}$}

Figure 1 shows the $\mathrm{CO}_{2}$ adsorption capacity for BPEI$\mathrm{SiO}_{2}\left(10 \% \mathrm{O}_{2}\right)$ and $\mathrm{LPEI}^{-\mathrm{SiO}_{2}}\left(10 \% \mathrm{O}_{2}\right)$, as well as BPEI-

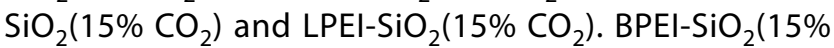
$\left.\mathrm{CO}_{2}\right)$ and $\mathrm{LPEI}-\mathrm{SiO}_{2}\left(15 \% \mathrm{CO}_{2}\right)$ exhibited a relatively stable $\mathrm{CO}_{2}$ adsorption performance during the tests. However, BPEI-SiO $2\left(10 \% \mathrm{O}_{2}\right)$ lost $23.0 \%$ of its original $\mathrm{CO}_{2}$ adsorption capacity by the 199 th cycle. In contrast, $\mathrm{LPEI}_{2} \mathrm{SiO}_{2}(10 \%$ $\mathrm{O}_{2}$ ) displayed almost the same stable performance as LPEI-SiO ${ }_{2}\left(15 \% \mathrm{CO}_{2}\right)$ and only lost approximately $3.6 \%$ of its original $\mathrm{CO}_{2}$ adsorption capacity by the 199th cycle. The $\mathrm{CO}_{2}$ cyclic adsorption-desorption results demonstrate that LPEI is much more resistant to oxidation by $\mathrm{O}_{2}$ than BPEI, which is consistent with previous research [37].

Figure 2a shows the DRIFT spectra of $\mathrm{BPEI}-\mathrm{SiO}_{2}, \mathrm{BPEI}-$ $\mathrm{SiO}_{2}\left(15 \% \mathrm{CO}_{2}\right)$, and $\mathrm{BPEI}^{-\mathrm{SiO}_{2}}\left(10 \% \mathrm{O}_{2}\right)$, and Fig. $2 \mathrm{~b}$ shows the DRIFT spectra of LPEI-SiO ${ }_{2}, \mathrm{LPEI}-\mathrm{SiO}_{2}\left(15 \% \mathrm{CO}_{2}\right)$, and LPEI-SiO ${ }_{2}\left(10 \% \mathrm{O}_{2}\right)$. Among the DRIFT spectra of BPEI-SiO ${ }_{2}$, BPEI-SiO $2\left(15 \% \mathrm{CO}_{2}\right)$, and BPEI-SiO $2\left(10 \% \mathrm{O}_{2}\right)$, the most apparent difference is the peak at $1666 \mathrm{~cm}^{-1}$. The weak peak in the case of $\mathrm{BPEI}-\mathrm{SiO}_{2}$ represents the $\mathrm{C}=\mathrm{O}$ stretching

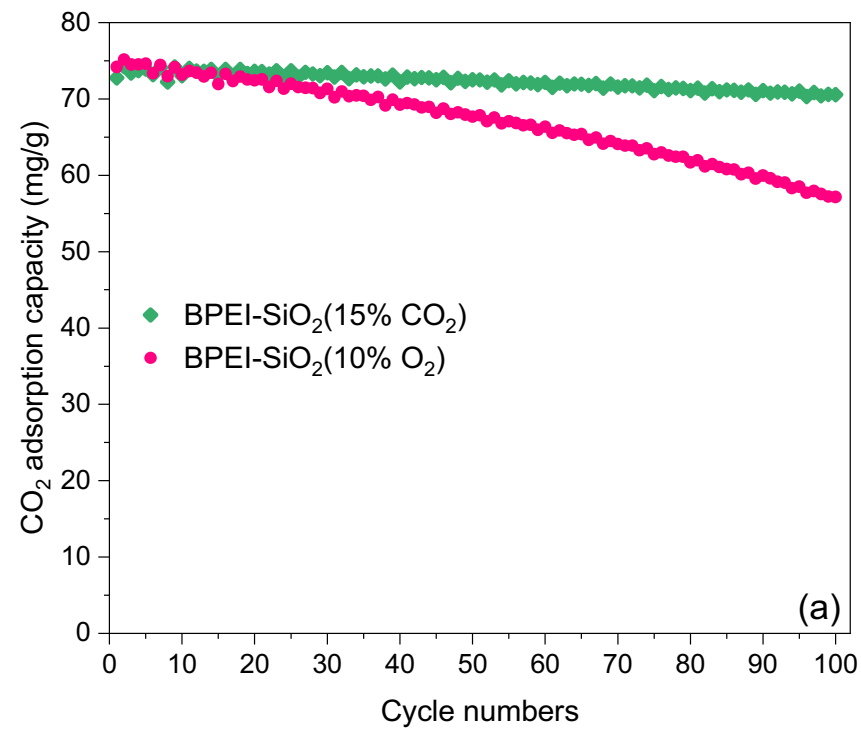

vibration in carbamate and carbamic acid formed by adsorbing $\mathrm{CO}_{2}$ from the atmosphere [13, 52-56]. The peak's absorption intensity in BPEI-SiO ${ }_{2}\left(15 \% \mathrm{CO}_{2}\right)$ is slightly stronger than in $\mathrm{BPEI}_{-} \mathrm{SiO}_{2}$ but weaker than in $\mathrm{BPEI}-$ $\mathrm{SiO}_{2}\left(10 \% \mathrm{O}_{2}\right)$, mainly due to the $\mathrm{C}=\mathrm{O}$ vibration in urea linkages $[13,57]$. For BPEI-SiO $2\left(10 \% \mathrm{O}_{2}\right)$, the peak at $1666 \mathrm{~cm}^{-1}$ becomes very prominent and is likely associated with the oxidation of $\mathrm{BPEI}-\mathrm{SiO}_{2}$ by $\mathrm{O}_{2}$ for various reasons. Bali et al. $[38,45]$ assigned a similar IR peak, located at $1693 \mathrm{~cm}^{-1}$, as the $\mathrm{C}=\mathrm{O}$ stretching vibration of amide, acid, and/or imide. Wang et al. $[39,58]$ assigned a similar band $\left(1659 \mathrm{~cm}^{-1}\right)$ as the amide's $C=0$ stretching vibration. Srikanth et al. $[41,53]$ assigned a similar peak at $1670 \mathrm{~cm}^{-1}$ as the $\mathrm{C}=\mathrm{O}$ stretching vibration in amide overlapping with the $\mathrm{N}=\mathrm{O}$ stretching vibration in nitrites. Additionally, Yu et al. [40, 52] assigned a broad band at $1660-1680 \mathrm{~cm}^{-1}$ as the $C=O$ vibration in amide overlapping with the $\mathrm{N}=\mathrm{O}$ vibration in nitrites. Gebald et al. $[42,54]$ assigned a similar peak $\left(1670 \mathrm{~cm}^{-1}\right)$ as the $\mathrm{C}=\mathrm{N}$ vibration in oxime/imine/nitrile and the $C=O$ vibration in amide/imide. Calleja et al. [43] assigned a similar peak at $1667 \mathrm{~cm}^{-1}$ as the $\mathrm{C}=\mathrm{N}$ stretching vibration of imine, oxime, and/or nitrone. Assignment of this peak $\left(1666 \mathrm{~cm}^{-1}\right)$ in the DRIFT spectra of $\mathrm{BPEI}^{-\mathrm{SiO}_{2}}$ $\left(10 \% \mathrm{O}_{2}\right)$ is difficult based solely on relevant literature results. Therefore, further analysis was performed.

Figure $2 \mathrm{~b}$ shows a weak peak at $1560 \mathrm{~cm}^{-1}$ for LPEI$\mathrm{SiO}_{2}$, attributed to the $\mathrm{COO}^{-}$stretching vibration in carbamate due to adsorption of $\mathrm{CO}_{2}$ from the atmosphere [56]. However, the peak becomes more prominent for LPEI-SiO $2\left(15 \% \mathrm{CO}_{2}\right)$ and LPEI-SiO $2\left(10 \% \mathrm{O}_{2}\right)$ due to the C-N stretching vibration of urea linkages $[53-55,59]$. In the DRIFT spectra of LPEI-SiO 2 and LPEI-SiO ${ }_{2}\left(15 \% \mathrm{CO}_{2}\right)$,

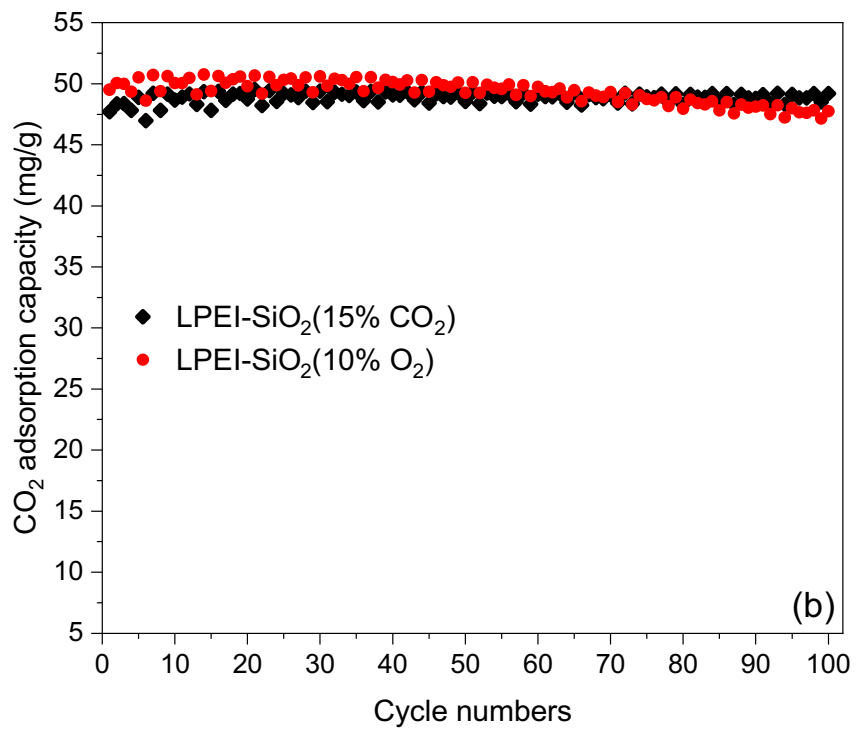

Fig. $1 \mathrm{CO}_{2}$ cyclic adsorption-desorption results for a BPEI-SiO ${ }_{2}\left(15 \% \mathrm{CO}_{2}\right)$ and $\mathrm{BPEI}-\mathrm{SiO}_{2}\left(10 \% \mathrm{O}_{2}\right)$ and b $\mathrm{LPEI}_{-} \mathrm{SiO} \mathrm{O}_{2}\left(15 \% \mathrm{CO}_{2}\right)$ and $\mathrm{LPEI}-$ $\mathrm{SiO}_{2}\left(10 \% \mathrm{O}_{2}\right)$ 

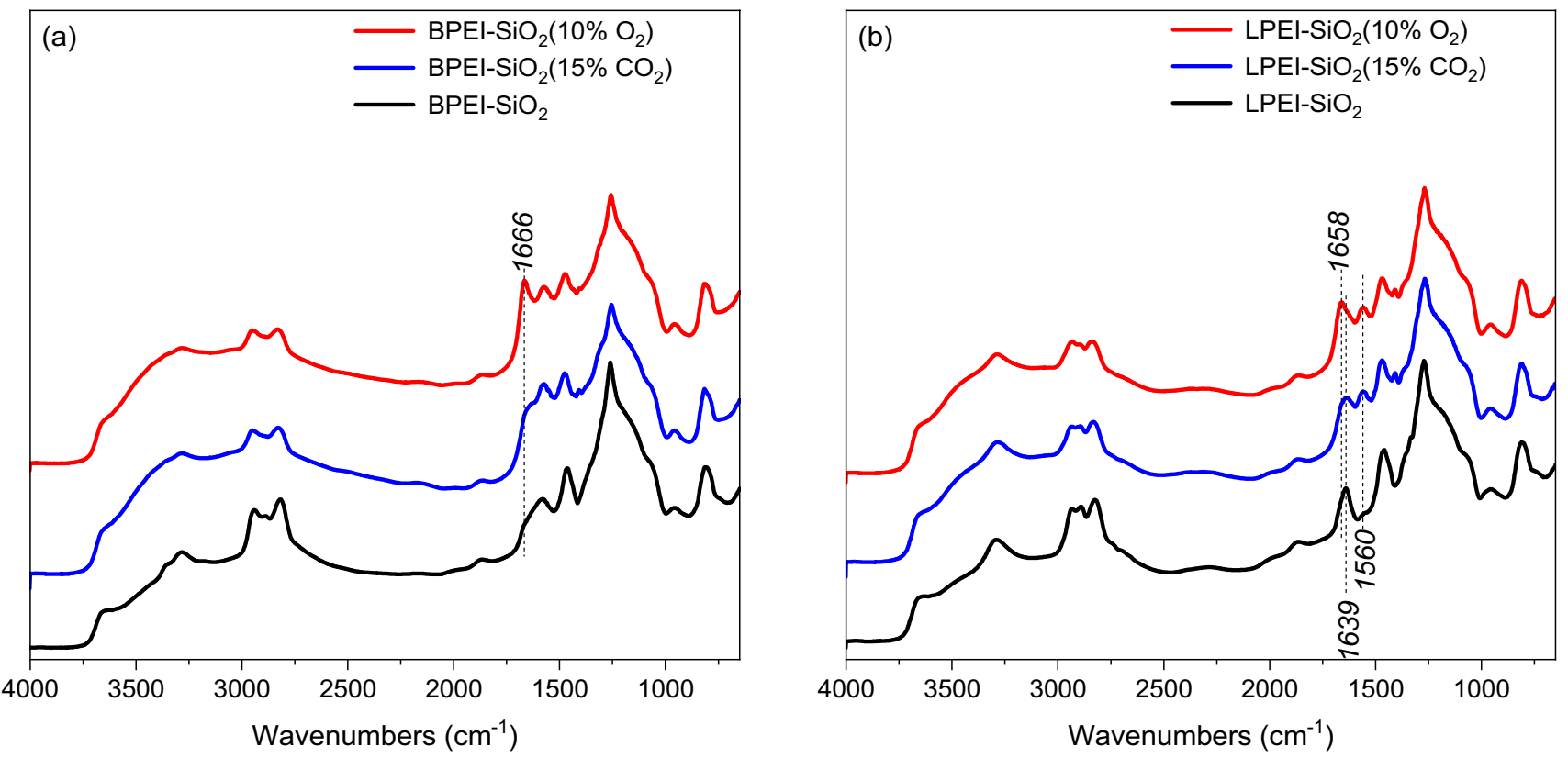

Fig. 2 DRIFT spectra of a BPEI-SiO ${ }_{2}, \mathrm{BPEI}_{-} \mathrm{SiO}_{2}\left(15 \% \mathrm{CO}_{2}\right)$, and BPEI-SiO $2\left(10 \% \mathrm{O}_{2}\right)$ and $\mathbf{b} \mathrm{LPEI}-\mathrm{SiO}_{2}, \mathrm{LPEI}_{2} \mathrm{SiO}_{2}\left(15 \% \mathrm{CO}_{2}\right)$, and LPEI-SiO $2\left(10 \% \mathrm{O}_{2}\right)$

a peak at $1639 \mathrm{~cm}^{-1}$, attributed to the $\mathrm{N}-\mathrm{H}$ deformation vibration of the secondary amine in LPEI [60], was observed. However, in the IR spectra of LPEI-SiO $2(10 \%$ $\mathrm{O}_{2}$ ), the peak at $1639 \mathrm{~cm}^{-1}$ is obscured by a prominent peak at $1658 \mathrm{~cm}^{-1}$, most likely the $\mathrm{C}=\mathrm{O}$ stretching vibration from the oxidization of $\mathrm{LPEI}-\mathrm{SiO}_{2}$.

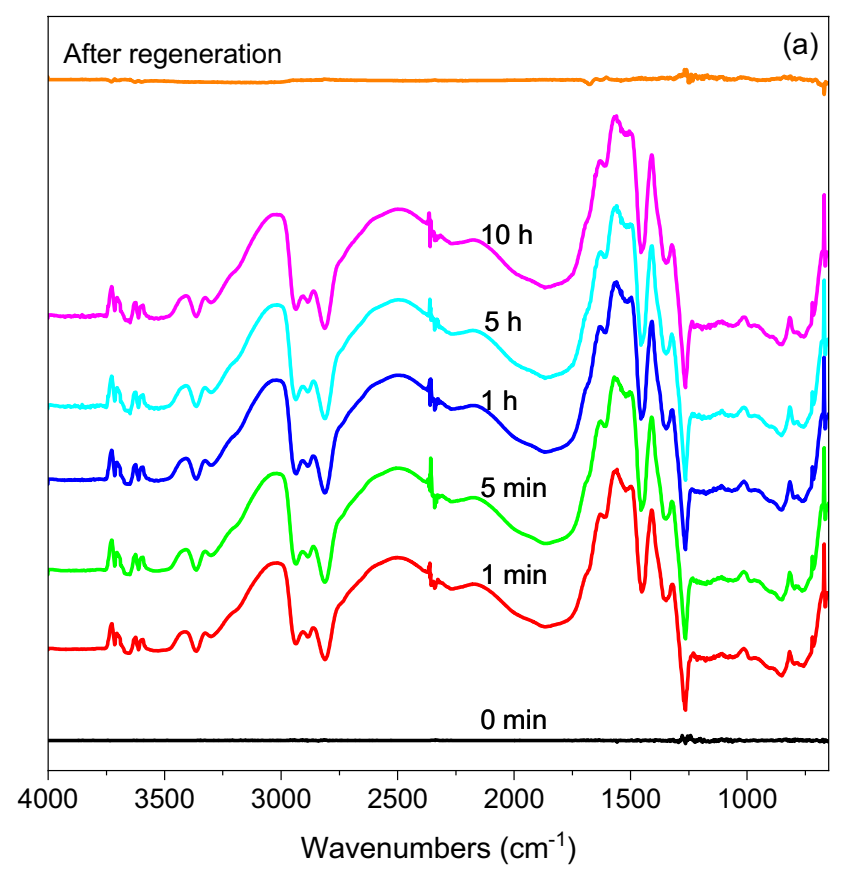

Figure $3 a$ and $b$ show the in situ DRIFT spectra of BPEI$\mathrm{SiO}_{2}$ and $\mathrm{LPEI}-\mathrm{SiO}_{2}$ when interacting with gas $1\left(15 \% \mathrm{CO}_{2}\right.$ balanced with $\mathrm{N}_{2}$ ). No apparent changes in the DRIFT spectra were observed during the interaction. After regeneration, the flat line spectrum in Fig. 3a indicated no noticeable degradation induced by $\mathrm{CO}_{2}$. In Fig. 3b, a negative

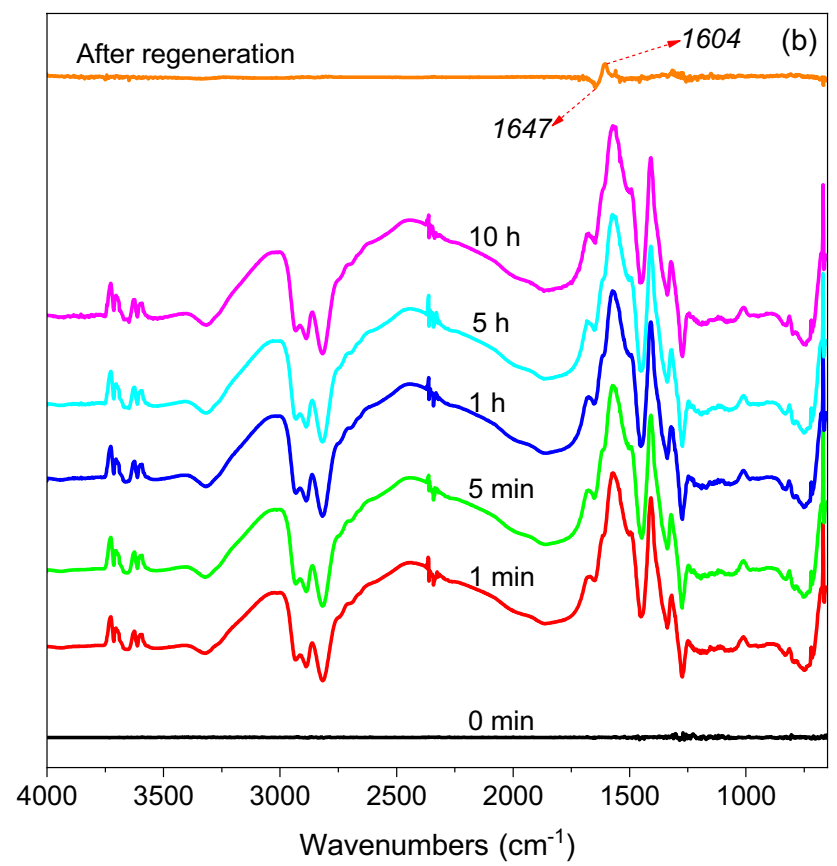

Fig. 3 In situ DRIFT spectra of $\mathbf{a}$ BPEI-SiO ${ }_{2}$ and $\mathbf{b}$ LPEI-SiO ${ }_{2}$ when interacting with gas $1\left(15 \% \mathrm{CO}_{2}\right.$ balanced with $\left.\mathrm{N}_{2}\right)$ 
peak at $1647 \mathrm{~cm}^{-1}$ and a positive peak at $1604 \mathrm{~cm}^{-1}$ were observed after regeneration, which is most likely due to the removal of chemically adsorbed $\mathrm{H}_{2} \mathrm{O}$ in $\mathrm{LPEI}-\mathrm{SiO}_{2}$.

Figure $4 a$ and $b$ show the in situ DRIFT spectra of BPEI$\mathrm{SiO}_{2}$ and $\mathrm{LPEI}-\mathrm{SiO}_{2}$, respectively, when interacting with $10 \% \mathrm{O}_{2}\left(15 \% \mathrm{CO}_{2}\right.$ and $10 \% \mathrm{O}_{2}$ balanced with $\left.\mathrm{N}_{2}\right)$. No apparent changes in the DRIFT spectra were observed during the interaction. After a 10-h interaction, no peaks indicating oxidation by $\mathrm{O}_{2}$ were observed in the DRIFT spectra of regenerated $\mathrm{BPEI}-\mathrm{SiO}_{2}$. A weak peak at $1670 \mathrm{~cm}^{-1}$ in the DRIFT spectra of regenerated $\mathrm{LPEI}^{-\mathrm{SiO}_{2}}$ was attributed to the $\mathrm{C}=\mathrm{O}$ vibration derived from oxidation by $\mathrm{O}_{2}$. After a 24-h interaction, the peak size at $1670 \mathrm{~cm}^{-1}$ increased in the DRIFT spectra of regenerated $\mathrm{LPEI}^{-\mathrm{SiO}_{2}}$. In the DRIFT spectra of regenerated $\mathrm{BPEI}-\mathrm{SiO}_{2}$, two positive peaks appeared at $1670 \mathrm{~cm}^{-1}$ and $1606 \mathrm{~cm}^{-1}$ and two negative peaks at $2941 \mathrm{~cm}^{-1}$ and $2817 \mathrm{~cm}^{-1}$. The two negative peaks $\left(2941 \mathrm{~cm}^{-1}\right.$ and $\left.2817 \mathrm{~cm}^{-1}\right)$ corresponded to the $\mathrm{C}-\mathrm{H}$ asymmetric and symmetric stretching vibration [56, $61,62]$, indicating the loss of $-\mathrm{CH}_{2}-$ groups in BPEl. The positive peak at $1670 \mathrm{~cm}^{-1}$ is likely due to the $C=O$ stretching vibration, and the positive peak at $1606 \mathrm{~cm}^{-1}$ indicates $\mathrm{C}=\mathrm{N}$ vibration [37]. We concluded that $\mathrm{O}_{2}$ oxidizes $-\mathrm{CH}_{2}$ - groups in $\mathrm{BPEl}$ to form $\mathrm{C}=\mathrm{O}$ and can also oxidize $-\mathrm{CH}_{2}-\mathrm{NH}$ - to form $\mathrm{C}=\mathrm{N}$ groups. The $\mathrm{C}=\mathrm{O}$ pathway seems to dominate based on the absorption intensity of the $\mathrm{C}=\mathrm{O}$ peak $\left(1670 \mathrm{~cm}^{-1}\right)$, which is much stronger than the $\mathrm{C}=\mathrm{N}$ peak $\left(1606 \mathrm{~cm}^{-1}\right)$. In LPEl, $\mathrm{O}_{2}$ oxidizes $-\mathrm{CH}_{2}$ - groups to form a small number of $\mathrm{C}=\mathrm{O}$ groups.

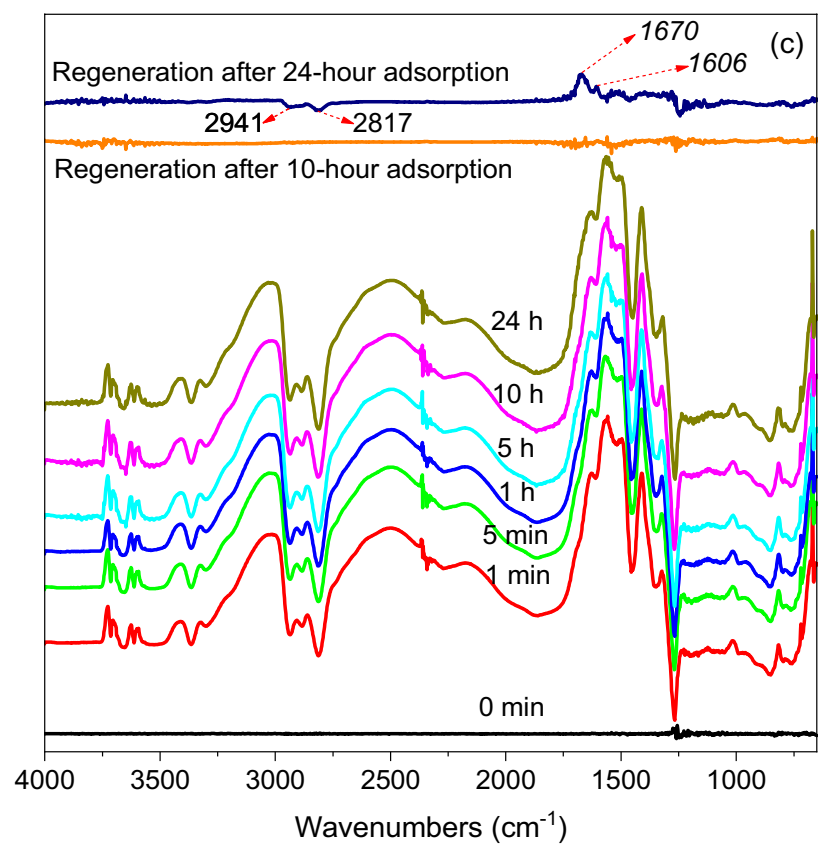

These results demonstrate that the oxidization of $\mathrm{BPEI}-$ $\mathrm{SiO}_{2}$ and $\mathrm{LPEI}-\mathrm{SiO}_{2}$ is a relatively slow process, but BPEI$\mathrm{SiO}_{2}$ is more readily oxidized than $\mathrm{LPEI}-\mathrm{SiO}_{2}$. We speculated that the $\mathrm{CO}_{2}$ adsorption capacity of $\mathrm{LPEI}-\mathrm{SiO}_{2}$ would also gradually decrease if we increased the test duration.

\subsection{The adverse effects of $\mathrm{SO}_{2}$}

Figure $5 \mathrm{a}$ and $\mathrm{b}$ show the $\mathrm{CO}_{2}$ adsorption capacity of $\mathrm{BPEI}-\mathrm{SiO}_{2}$ and $\mathrm{LPEI}-\mathrm{SiO}_{2}$ after exposure to $\mathrm{SO}_{2} \cdot \mathrm{SO}_{2}$ led to a severe decrease in $\mathrm{CO}_{2}$ adsorption capacity. An almost linear decrease in $\mathrm{CO}_{2}$ adsorption capacity was observed for both $\mathrm{BPEI}-\mathrm{SiO}_{2}$ and $\mathrm{LPEI}-\mathrm{SiO}_{2}$ after exposure to 10 or $50 \mathrm{ppm} \mathrm{SO} \mathrm{S}_{2}\left(15 \% \mathrm{CO}_{2}\right.$ and 10 or $50 \mathrm{ppm} \mathrm{SO}$ balanced with $\mathrm{N}_{2}$ ). The $\mathrm{CO}_{2}$ adsorption capacity of BPEI-SiO $\mathrm{Sin}_{2}$ and $\mathrm{LPEI}^{-\mathrm{SiO}_{2}}$ cumulatively decreased by $18.2 \%$ and $18.5 \%$ at $10 \mathrm{ppm} \mathrm{SO}$ and by $61.4 \%$ and $60.6 \%$ at 50 ppm SO $\mathrm{SO}_{2}$. When the level of $\mathrm{SO}_{2}$ reached $200 \mathrm{ppm}$, the $\mathrm{CO}_{2}$ adsorption capacity of $\mathrm{BPEI}_{-} \mathrm{SiO}_{2}$ and $\mathrm{LPEI}-\mathrm{SiO}_{2}$ respectively lost $89.0 \%$ and $78.5 \%$. And the decrease in the $\mathrm{CO}_{2}$ adsorption capacity occurred mainly in the first 50-60 cycles in the $200 \mathrm{ppm} \mathrm{SO} \mathrm{S}_{2}$ scenario. For example, the $\mathrm{CO}_{2}$ adsorption capacity of $\mathrm{BPEI}_{-} \mathrm{SiO}_{2}$ at the 60 th cycle and of $\mathrm{LPEI}-\mathrm{SiO}_{2}$ at the 50 th cycle decreased by $85.5 \%$ and $74.1 \%$, respectively. During subsequent cycles, the decreasing $\mathrm{CO}_{2}$ adsorption capacity reached a plateau. The stable $\mathrm{CO}_{2}$ adsorption performance in the plateaus may be due to the residual isolated amino groups, which could adsorb $\mathrm{CO}_{2}$ and, more importantly, could adsorb $\mathrm{SO}_{2}$ reversibly $[28,44,48,52]$.

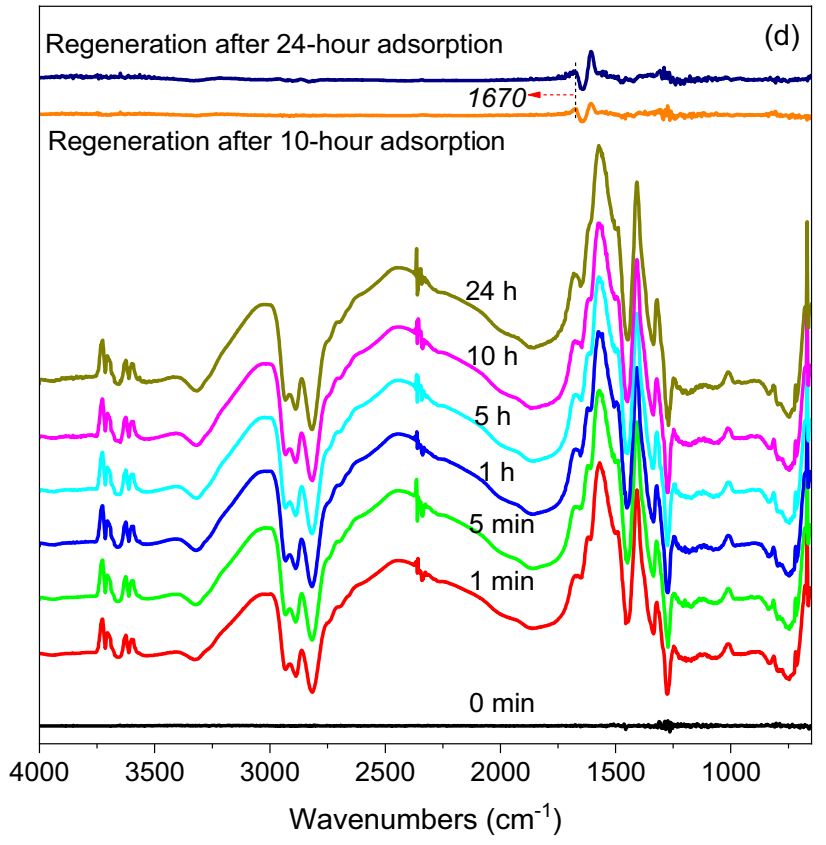

Fig. 4 In situ DRIFT spectra of $\mathbf{a} \mathrm{BPEI}-\mathrm{SiO}_{2}$, and $\mathbf{b}$ LPEI-SiO $\mathrm{S}_{2}$ during interaction with $10 \% \mathrm{O}_{2}\left(15 \% \mathrm{CO}_{2}\right.$ and $10 \% \mathrm{O}_{2}$ balanced with $\left.\mathrm{N}_{2}\right)$ 

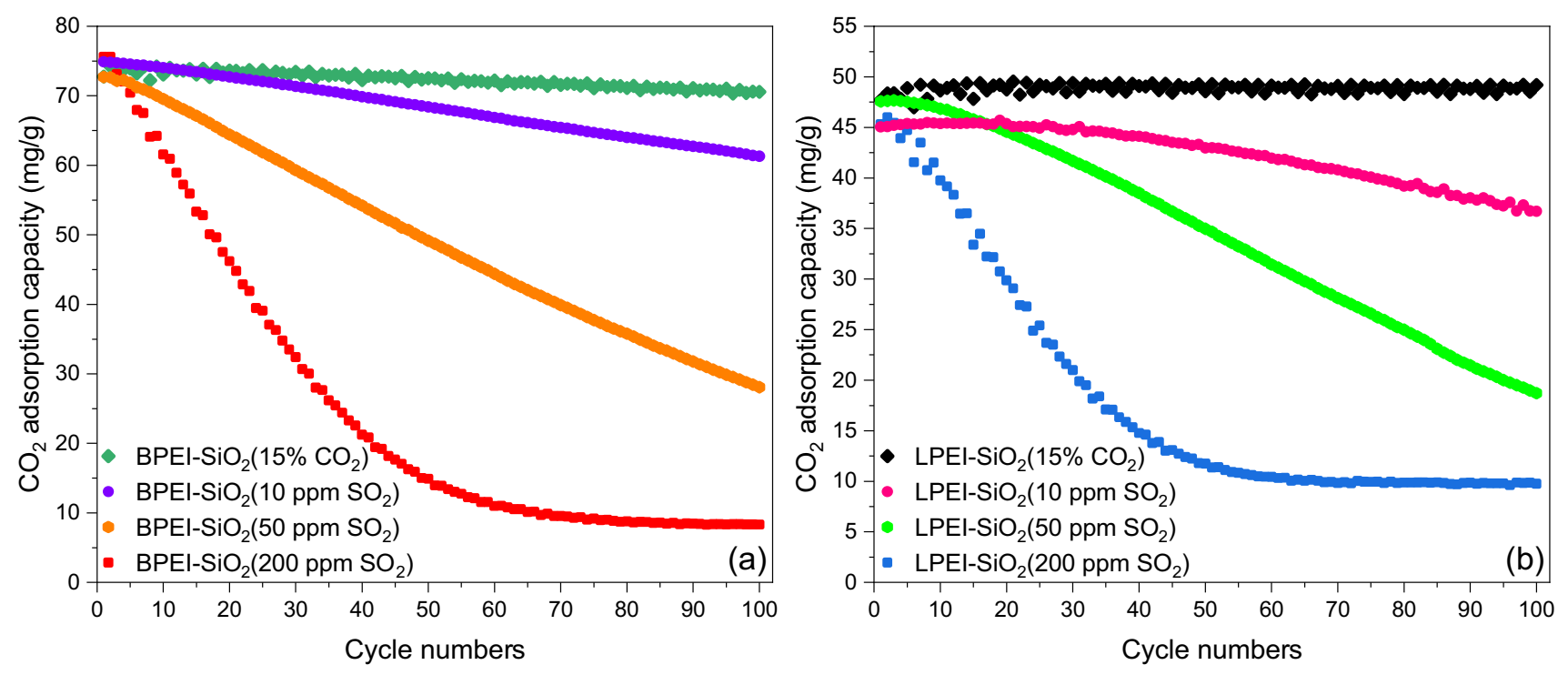

Fig. $5 \mathrm{CO}_{2}$ cyclic adsorption-desorption results for a $\left.\mathrm{BPEI}-\mathrm{SiO}_{2}\left(15 \% \mathrm{CO}_{2}\right), \mathrm{BPEI}-\mathrm{SiO}_{2}\left(10 \mathrm{ppm} \mathrm{SO}_{2}\right), \mathrm{BPEl}^{-\mathrm{SiO}}{ }_{2}(50 \mathrm{ppm} \mathrm{SO})_{2}\right)$, and $\mathrm{BPEl}-$

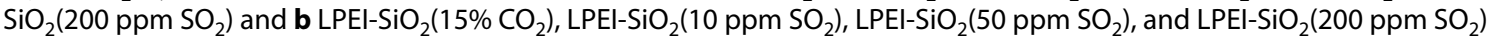

Figure 6a shows a peak at $1662 \mathrm{~cm}^{-1}$ for each sample, typically associated with the $\mathrm{C}=\mathrm{O}$ stretching vibration, but the absorption intensities differed significantly. For BPEI$\mathrm{SiO}_{2}$, the peak was derived from the $\mathrm{C}=\mathrm{O}$ stretching vibration in carbamate and carbamic acid due to adsorption of $\mathrm{CO}_{2}$ from the atmosphere $[13,52-56]$. For $\mathrm{BPEI}_{-} \mathrm{SiO}_{2}(15 \%$ $\left.\mathrm{CO}_{2}\right)$, the formation of urea linkages was most responsible for the peak $[13,57]$. For BPEl-SiO ${ }_{2}\left(10\right.$ ppm SO $\left._{2}\right)$, the peak's adsorption intensity was similar to that for $\mathrm{BPEI}^{-\mathrm{SiO}_{2}}(15 \%$
$\left.\mathrm{CO}_{2}\right)$. However, for $\mathrm{BPEI}-\mathrm{SiO}_{2}\left(50 \mathrm{ppm} \mathrm{\textrm {SO } _ { 2 }}\right)$ and BPEI$\left.\mathrm{SiO}_{2}(200 \text { ppm SO})_{2}\right)$, the peak's intensity increased, likely due to the affinity of $\mathrm{SO}_{2}$ to $\mathrm{BPEI}-\mathrm{SiO}_{2}$.

A similar phenomenon was observed at $1666 \mathrm{~cm}^{-1}$ in Fig. 6b. Meantime, two other peaks at $1496 \mathrm{~cm}^{-1}$ and $1560 \mathrm{~cm}^{-1}$, most likely attributed to the C-N stretching vibration of urea linkages [53-55,59], can also be observed in Fig. 6b. Thus, we postulate that the intense peak at $1666 \mathrm{~cm}^{-1}$ for $\mathrm{SO}_{2}$-exposed samples is due mainly
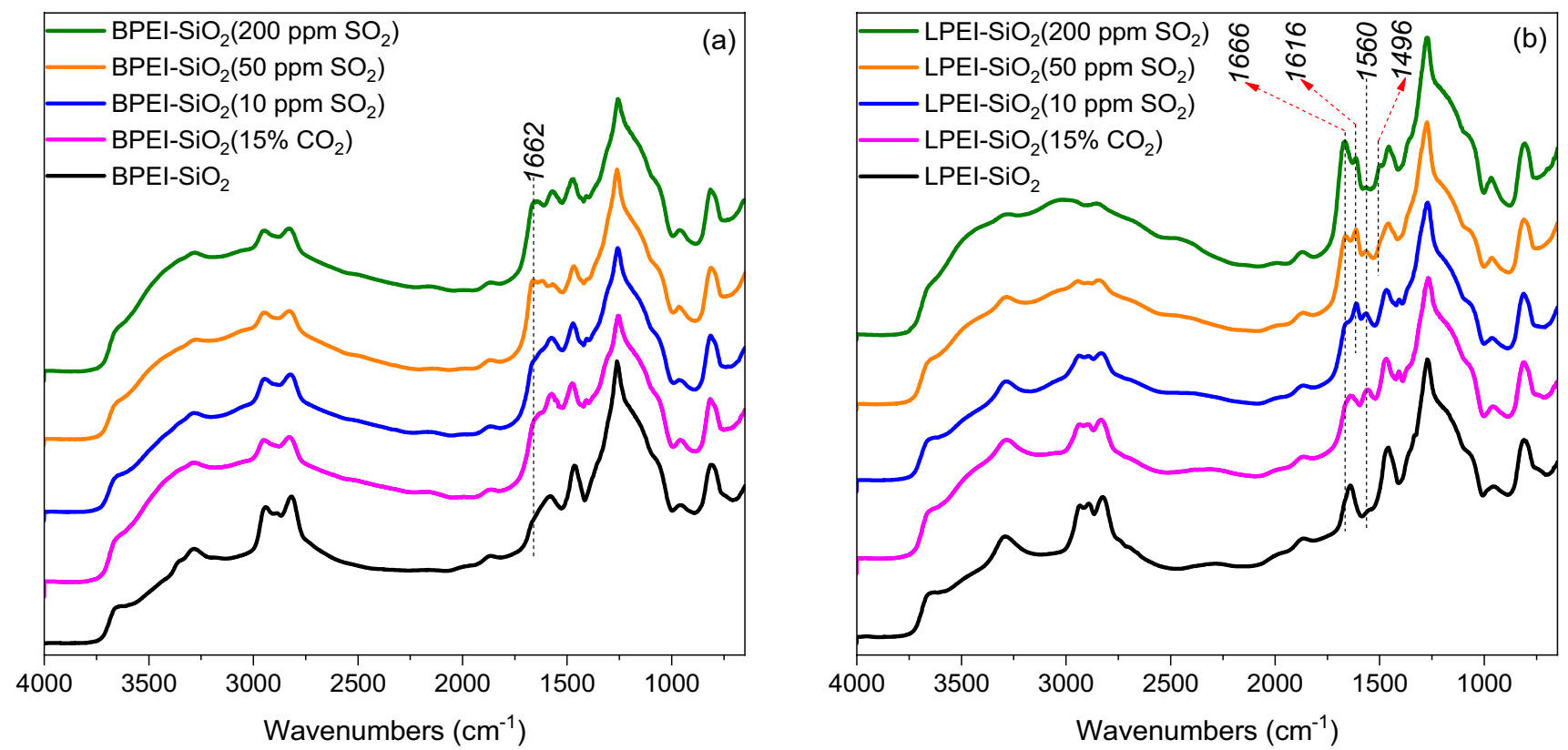

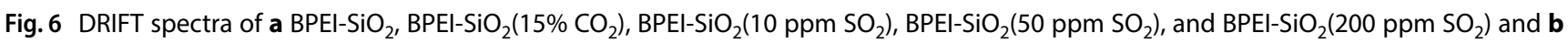

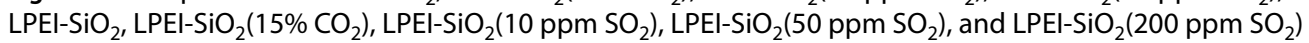

\section{SN Applied Sciences}



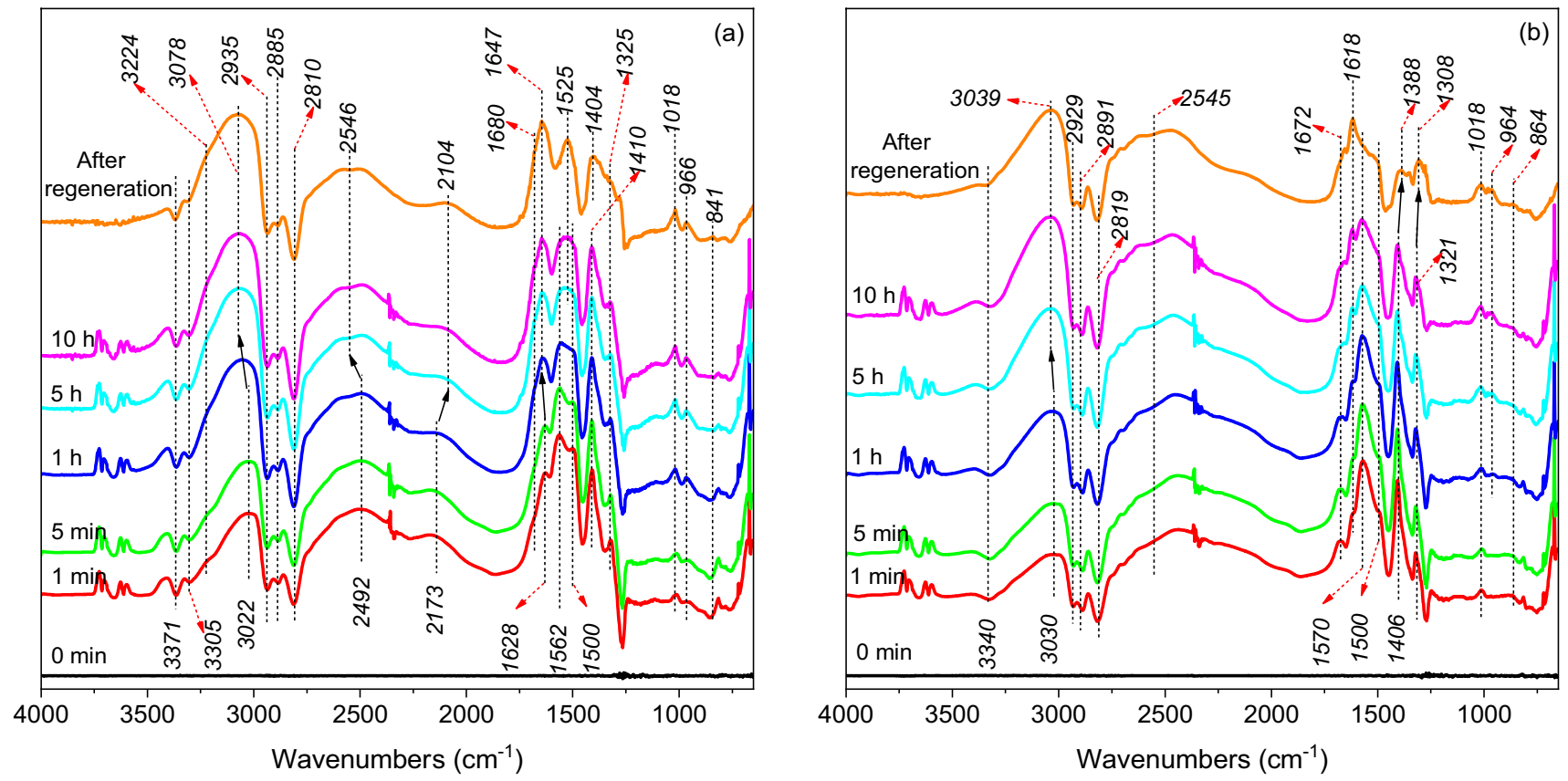

Fig. 7 In situ DRIFT spectra of $\mathbf{a} \mathrm{BPEI}_{-} \mathrm{SiO}_{2}$ and $\mathbf{b} \mathrm{LPEI}-\mathrm{SiO}_{2}$ during interaction with 200 ppm $\mathrm{SO}_{2}\left(15 \% \mathrm{CO}_{2}\right.$ and 200 ppm SO 2 balanced with $\mathrm{N}_{2}$ )

to the $\mathrm{C}=\mathrm{O}$ stretching vibration of urea linkages. The peak at $1662 \mathrm{~cm}^{-1}$ in Fig. 6 a may also represent the $\mathrm{C}=\mathrm{O}$ stretching vibration of urea linkages. Therefore, we concluded that $\mathrm{SO}_{2}$ promotes the formation of urea linkages when PEl functional adsorbents interact with $\mathrm{CO}_{2}$ streams containing $\mathrm{SO}_{2}$. Moreover, $\mathrm{NH}_{2}^{+}$deformation vibrations were observed at $1616 \mathrm{~cm}^{-1}$ in the DRIFT spectra of LPEI$\left.\mathrm{SiO}_{2}\left(10 \mathrm{ppm} \mathrm{SO}_{2}\right), \mathrm{LPEI}-\mathrm{SiO}_{2}(50 \mathrm{ppm} \mathrm{SO})_{2}\right)$, and LPEI-SiO 2 $\left.(200 \text { ppm SO})_{2}\right)[56,61,63]$ in Fig. 6b. These represent the formation of heat-stable $\mathrm{NH}_{2}{ }^{+}$-containing adducts between $\mathrm{SO}_{2}$ and $\mathrm{LPEI}-\mathrm{SiO}_{2}$.

Figure $7 a$ and $b$ show in situ DRIFT spectra of $\mathrm{BPEI}_{-\mathrm{SiO}_{2}}$ and $\mathrm{LPEI}-\mathrm{SiO}_{2}$, respectively, when interacting with $200 \mathrm{ppm}$ $\mathrm{SO}_{2}\left(15 \% \mathrm{CO}_{2}\right.$ and 200 ppm $\mathrm{SO}_{2}$ balanced with $\left.\mathrm{N}_{2}\right)$ at $75^{\circ} \mathrm{C}$. In Fig. 7a, the initial peak at $3022 \mathrm{~cm}^{-1}$, representing the $\mathrm{NH}_{3}{ }^{+}$/ $\mathrm{NH}_{2}{ }^{+}$vibration $[56,61,63]$, clearly strengthened and gradually shifted to $3078 \mathrm{~cm}^{-1}$ with prolonged interaction time. Similarly, the initial peak at $1628 \mathrm{~cm}^{-1}$, representing the $\mathrm{NH}_{3}^{+}$ vibration $[56,61,63]$, clearly strengthened and gradually shifted to $1647 \mathrm{~cm}^{-1}$. After regeneration, the two peaks had a high absorption intensity. The peak at $2546 \mathrm{~cm}^{-1}$, representing the $\mathrm{NH}_{3}{ }^{+} / \mathrm{NH}_{2}{ }^{+}$vibration $[56,61,64]$, and the peak at $2104 \mathrm{~cm}^{-1}$, representing the $\mathrm{NH}_{3}{ }^{+}$vibration $[56,61,64]$, were observed after regeneration. The two peaks at $1562 \mathrm{~cm}^{-1}$ and $1500 \mathrm{~cm}^{-1}$, which represent the $\mathrm{COO}^{-}$stretching vibration in carbamate $[52,56,61,64-66]$, disappeared after regeneration, implying the release of the adsorbed $\mathrm{CO}_{2}$. Therefore, the remaining $\mathrm{NH}_{3}{ }^{+} / \mathrm{NH}_{2}{ }^{+}$groups must originate from the formation of heat-stable $\mathrm{NH}_{3}{ }^{+} / \mathrm{NH}_{2}{ }^{+}$-containing adducts between $\mathrm{BPEI}-\mathrm{SiO}_{2}$ and $\mathrm{SO}_{2}$. Meanwhile, the peaks at $1018 \mathrm{~cm}^{-1}$ and $966 \mathrm{~cm}^{-1}$ most likely belong to the asymmetric and symmetric $S=0$ stretching vibration $[22,45,46$, $63,67]$, and the peak at $841 \mathrm{~cm}^{-1}$ represents the S-O stretching vibration $[46,68]$, which all suggest the existence of sulfur-containing products. All of the above peaks are observed at similar locations in Fig. 7b.

The above analysis demonstrates that $\mathrm{SO}_{2}$ reacted with BPEI and LPEI to form irreversible $\mathrm{NH}_{3}{ }^{+}-$and/or $\mathrm{NH}_{2}{ }^{+}$-containing adducts. Previous studies reported that sulfites and/or sulfates formed between $\mathrm{SO}_{2}$ and solid amine adsorbents $[17,44-46,49,68]$. As $\mathrm{H}_{2} \mathrm{O}$ and $\mathrm{O}_{2}$ were free during the interaction processes in this study, we hypothesized that the following Eqs. (1) and (2) describe a possible mechanism for the reactions between $\mathrm{SO}_{2}$ and amino groups [44, 69]. These equations are similar to the reaction between $\mathrm{CO}_{2}$ and amino groups under dry conditions (Eqs. (3) and (4)):

$\mathrm{R}_{1} \mathrm{R}_{2} \mathrm{NH}+\mathrm{SO}_{2} \leftrightarrow \mathrm{R}_{1} \mathrm{R}_{2} \mathrm{NH}^{+} \mathrm{SOO}^{-}$

$\mathrm{R}_{1} \mathrm{R}_{2} \mathrm{NH}+\mathrm{R}_{1} \mathrm{R}_{2} \mathrm{NH}^{+} \mathrm{SOO}^{-} \leftrightarrow \mathrm{R}_{1} \mathrm{R}_{2} \mathrm{NH}_{2}^{+}+\mathrm{R}_{1} \mathrm{R}_{2} \mathrm{NSOO}^{-}$

$\mathrm{R}_{1} \mathrm{R}_{2} \mathrm{NH}+\mathrm{CO}_{2} \leftrightarrow \mathrm{R}_{1} \mathrm{R}_{2} \mathrm{NH}^{+} \mathrm{COO}^{-}$

$\mathrm{R}_{1} \mathrm{R}_{2} \mathrm{NH}+\mathrm{R}_{1} \mathrm{R}_{2} \mathrm{NH}^{+} \mathrm{COO}^{-} \leftrightarrow \mathrm{R}_{1} \mathrm{R}_{2} \mathrm{NH}_{2}^{+}+\mathrm{R}_{1} \mathrm{R}_{2} \mathrm{NCOO}^{-}$

$\mathrm{R}_{1}, \mathrm{R}_{2}=\mathrm{H}$ or $\mathrm{CH}_{2}$ 
The peak at $1680 \mathrm{~cm}^{-1}$ in Fig. $7 \mathrm{a}$ and at $1672 \mathrm{~cm}^{-1}$ in Fig. $7 \mathrm{~b}$ were both observed after regeneration. They most likely belong to the $\mathrm{C}=\mathrm{O}$ stretching vibration of urea linkages. In previous research [13], we found that the in situ DRIFT peak representing $\mathrm{C}=\mathrm{O}$ in urea linkages was extremely weak after $11 \mathrm{~h}$ of interaction between pure $\mathrm{CO}_{2}$ and the BPEI $(\mathrm{MW}=600 \mathrm{Da})$ functional adsorbent at $75^{\circ} \mathrm{C}$. Thus, the intense peaks observed after regeneration must be derived from the influence of $\mathrm{SO}_{2}$ (Fig. $7 \mathrm{a}$ and b). As we had speculated, $\mathrm{SO}_{2}$ can promote the formation of urea linkages between PEI functional adsorbents and $\mathrm{CO}_{2}$.

The in situ DRIFT spectra of $\mathrm{BPEI}^{-\mathrm{SiO}_{2}}$ or $\mathrm{LPEI}-\mathrm{SiO}_{2}$ in the presence of $10 \mathrm{ppm} \mathrm{SO} \mathrm{S}_{2}\left(15 \% \mathrm{CO}_{2}\right.$ and $10 \mathrm{ppm} \mathrm{SO}$ balanced with $\mathrm{N}_{2}$ ) are shown in Figures $\mathrm{S} 7, \mathrm{~S} 8$, and $\mathrm{S} 9$ in the Supplementary Information. The spectra were similar to those in the $200 \mathrm{ppm} \mathrm{SO}_{2}$ scenario, but the absorption intensity was much lower in the $10 \mathrm{ppm} \mathrm{SO}_{2}$ scenario.

\subsection{The adverse effects of $\mathrm{NO}_{2}$}

Generally, $\mathrm{NO}_{2}$ accounts for only $5 \%$ or less of the total $\mathrm{NO}_{x}$ in flue gas [70]. In this study, we used a concentration of 10 ppm $\mathrm{NO}_{2}\left(15 \% \mathrm{CO}_{2}\right.$ and 10 ppm NO $\mathrm{Na}_{2}$ balanced with $\left.\mathrm{N}_{2}\right)$ to investigate the adverse effects of $\mathrm{NO}_{2}$ on $\mathrm{PEl}$ functional adsorbents. As a reference, $200 \mathrm{ppm} \mathrm{NO} \mathrm{N}_{2}\left(15 \% \mathrm{CO}_{2}\right.$ and 200 ppm NO $\mathrm{N}_{2}$ balanced with $\mathrm{N}_{2}$ ) was also investigated. $\mathrm{CO}_{2}$ cyclic adsorption-desorption tests (Fig. 8a and b) showed excellent $\mathrm{CO}_{2}$ adsorption stabilities for both $\mathrm{BPEI}-\mathrm{SiO}_{2}$ and $\mathrm{LPEI}-\mathrm{SiO}_{2}$ under the $10 \mathrm{ppm} \mathrm{NO} \mathrm{N}_{2}$ scenario. However, under the 200 ppm NO${ }_{2}$ scenario, the $\mathrm{CO}_{2}$ adsorption capacity of $\mathrm{BPEI}-\mathrm{SiO}_{2}$ and $\mathrm{LPEI}-\mathrm{SiO}_{2}$ showed an almost linear decline and were decreased by $49.6 \%$ and $49.5 \%$, respectively.

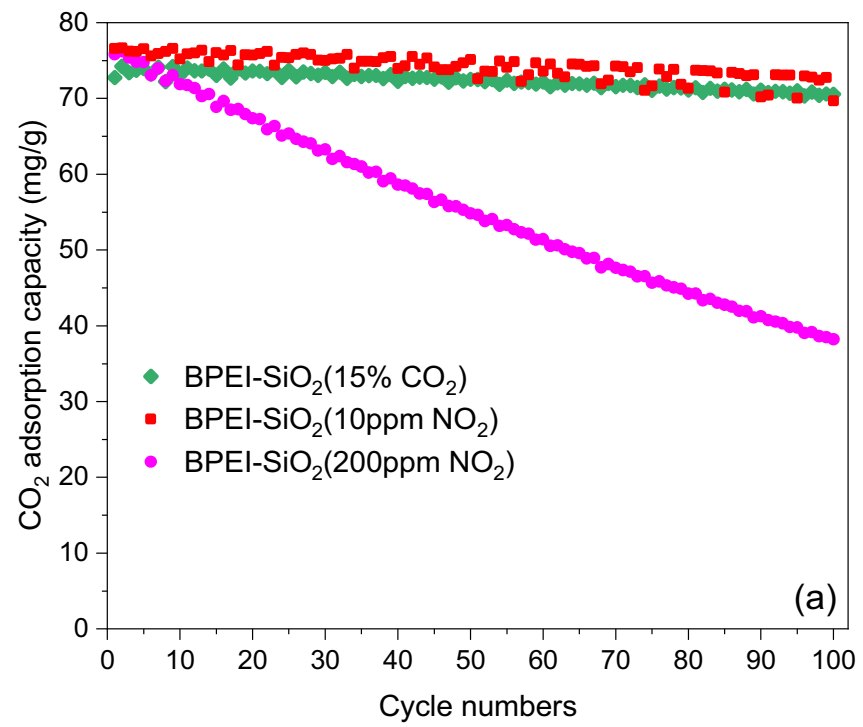

In Fig. 9a and b, a sharp peak at $1666 \mathrm{~cm}^{-1}$ was observed for both $\mathrm{BPEI}-\mathrm{SiO}_{2}\left(200 \mathrm{ppm} \mathrm{NO} \mathrm{N}_{2}\right)$ and LPEI$\mathrm{SiO}_{2}(200 \mathrm{ppm} \mathrm{NO})_{2}$. The peaks are possibly associated with the $\mathrm{C}=\mathrm{O}$ stretching vibration in urea linkages. However, in the presence of $\mathrm{NO}_{2}$, it is difficult to exclude the $\mathrm{N}=\mathrm{O}$ stretching vibration in nitrites and/or nitrates for this peak $\left(1666 \mathrm{~cm}^{-1}\right)$ [63]. Furthermore, a peak at approximately $1361 \mathrm{~cm}^{-1}$ was observed in the DRIFT spectra of $\mathrm{BPEI}-\mathrm{SiO}_{2}(200 \mathrm{ppm} \mathrm{NO})_{2}$ and $\mathrm{LPEI}-\mathrm{SiO}_{2}(200 \mathrm{ppm} \mathrm{NO})_{2}$, most likely associated with the formation of $\mathrm{N}$-nitroso compounds [71, 72]. In Fig. 9a, the DRIFT spectra of BPEI$\left.\mathrm{SiO}_{2}(10 \mathrm{ppm} \mathrm{NO})_{2}\right)$ are similar to those of BPEI-SiO $2(15 \%$ $\mathrm{CO}_{2}$ ). In Fig. $9 \mathrm{~b}$, a peak at $1612 \mathrm{~cm}^{-1}$, representing the $\mathrm{NH}_{2}{ }^{+}$ deformation vibration $[56,61,63]$, was observed for both

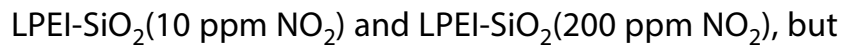
not for $\mathrm{LPEI}-\mathrm{SiO}_{2}$ or $\mathrm{LPEI}-\mathrm{SiO}_{2}\left(15 \% \mathrm{CO}_{2}\right)$.

Figure 10a and $b$ exhibit the in situ DRIFT spectra of $\mathrm{BPEI}-\mathrm{SiO}_{2}$ and $\mathrm{LPEI}-\mathrm{SiO}_{2}$ during interaction with $200 \mathrm{ppm}$ $\mathrm{NO}_{2}\left(15 \% \mathrm{CO}_{2}\right.$ and $200 \mathrm{ppm} \mathrm{NO} \mathrm{N}_{2}$ balanced with $\left.\mathrm{N}_{2}\right)$. Figure 10a shows that the initial peak at $3022 \mathrm{~cm}^{-1}$ gradually strengthened and shifted to $3074 \mathrm{~cm}^{-1}$ during prolonged interaction time. This peak represents the $\mathrm{NH}_{3}{ }^{+} / \mathrm{NH}_{2}{ }^{+}$stretching vibration $[56,61,63]$ and was still prominent after regeneration. The peak at approximately $2505 \mathrm{~cm}^{-1}$ represents the $\mathrm{NH}_{3}{ }^{+} / \mathrm{NH}_{2}{ }^{+}$stretching vibration $[56,61,64]$, and the peaks at approximately $2162 \mathrm{~cm}^{-1}$ and $1631 \mathrm{~cm}^{-1}$ represent the $\mathrm{NH}_{3}{ }^{+}$vibration $[56,61,63$, 64] and were observed after regeneration. The peak at $1651 \mathrm{~cm}^{-1}$, most likely due to the $\mathrm{N}=\mathrm{O}$ vibration in nitrites and/or nitrates [63], emerged and gradually strengthened with prolonged interaction time, and the sharp peak was still present after regeneration. Furthermore, the peak at

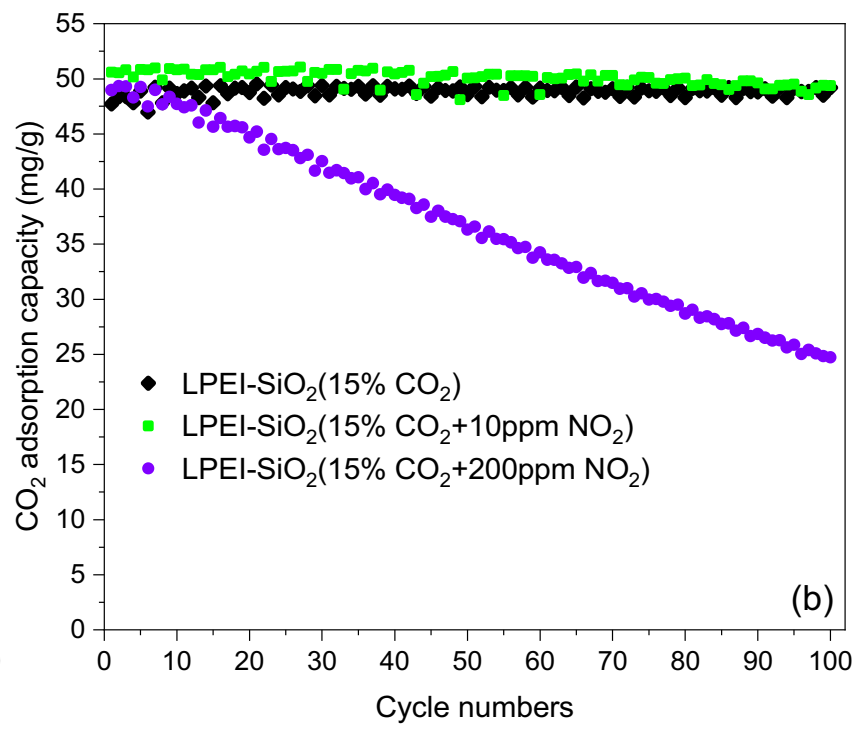

Fig. $8 \mathrm{CO}_{2}$ cyclic adsorption-desorption results for a BPEI-SiO${ }_{2}\left(15 \% \mathrm{CO}_{2}\right), \mathrm{BPEI}_{-} \mathrm{SiO}_{2}(10 \mathrm{ppm} \mathrm{NO})_{2}$, and $\mathrm{BPEI}_{-} \mathrm{SiO} \mathrm{O}_{2}(200 \mathrm{ppm} \mathrm{NO} 2)$ and $\mathbf{b} \mathrm{LPEI}-$ $\mathrm{SiO}_{2}\left(15 \% \mathrm{CO}_{2}\right), \mathrm{LPEI}_{-} \mathrm{SiO}_{2}(10 \mathrm{ppm} \mathrm{NO})_{2}$, and LPEI-SiO $2(200 \mathrm{ppm} \mathrm{NO})_{2}$ 

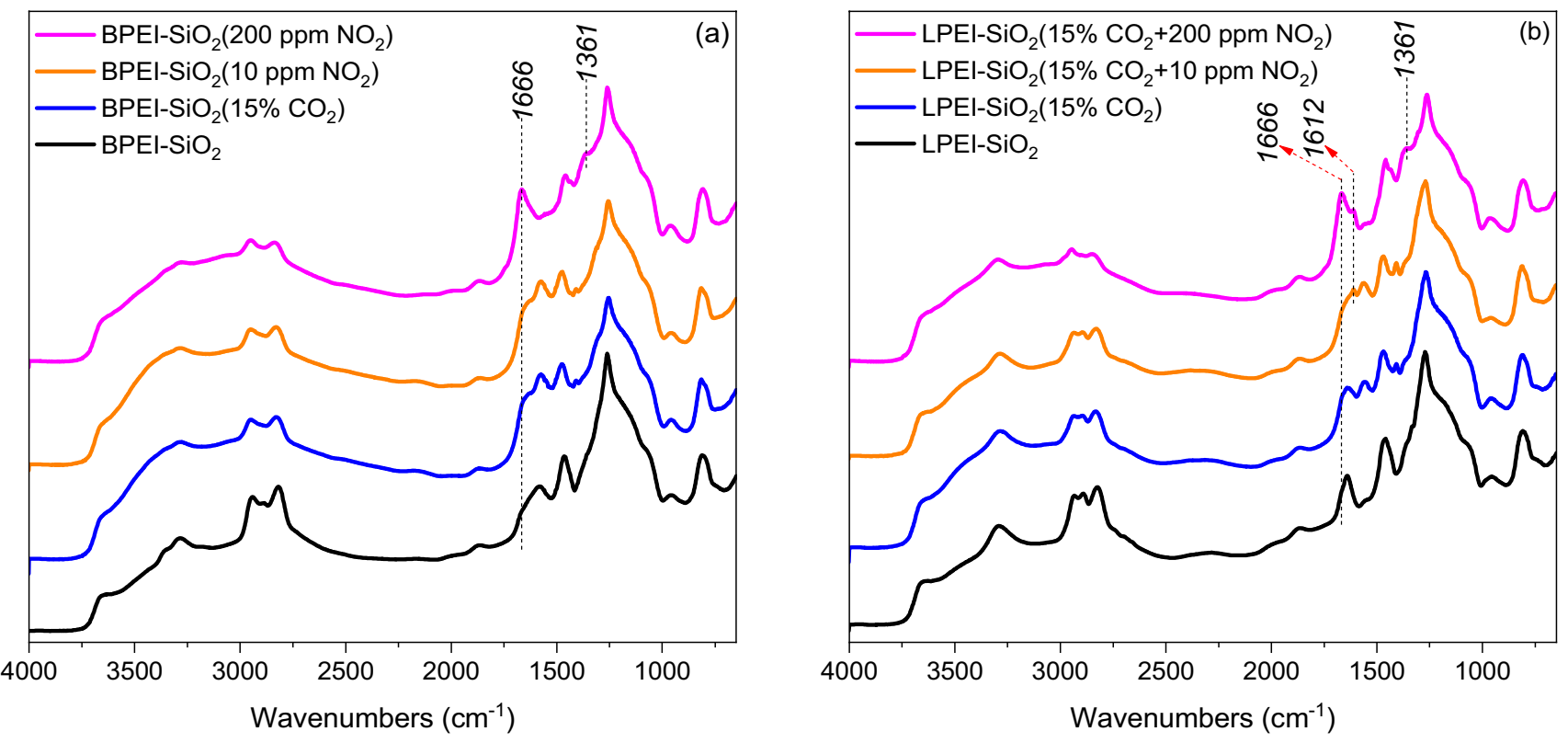

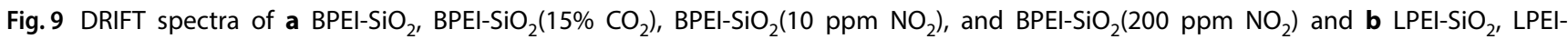

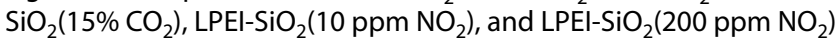

$802 \mathrm{~cm}^{-1}$, representing the $\mathrm{C}-\mathrm{N}$ stretching vibration in nitrites [63], and the peak at $1126 \mathrm{~cm}^{-1}$, representing $\mathrm{N}-\mathrm{N}$ stretching vibration in nitrates $[46,63]$, both remained after regeneration.

All of the above peaks are observed at similar locations in Fig. 10b. Therefore, the formation of $\mathrm{NH}_{3}{ }^{+}$and/or $\mathrm{NH}_{2}{ }^{+}$-containing nitrites and/or nitrates is an important route for the degradation of $\mathrm{BPEI}_{-} \mathrm{SiO}_{2}$ and $\mathrm{LPEI}-\mathrm{SiO}_{2}$. Considering $\mathrm{O}_{2}$ and $\mathrm{H}_{2} \mathrm{O}$ are free during the interaction processes, we speculate that the possible formation mechanism of nitrites and nitrates is depicted in Eqs. (5) to (9) [73]:

$\mathrm{R}_{1} \mathrm{R}_{2} \mathrm{NH}+\mathrm{NO}_{2} \leftrightarrow \mathrm{R}_{1} \mathrm{R}_{2} \mathrm{NH}^{+} \mathrm{NOO}^{-}$

$\mathrm{R}_{1} \mathrm{R}_{2} \mathrm{NH}+\mathrm{R}_{1} \mathrm{R}_{2} \mathrm{NH}^{+} \mathrm{NOO}^{-} \leftrightarrow \mathrm{R}_{1} \mathrm{R}_{2} \mathrm{NH}_{2}^{+}+\mathrm{R}_{1} \mathrm{R}_{2} \mathrm{NNOO}^{-}$

$\mathrm{NO}_{2}+\mathrm{NO}_{2} \leftrightarrow \mathrm{N}_{2} \mathrm{O}_{4}$

$\mathrm{R}_{1} \mathrm{R}_{2} \mathrm{NH}+\mathrm{N}_{2} \mathrm{O}_{4} \leftrightarrow \mathrm{R}_{1} \mathrm{R}_{2} \mathrm{NH}^{+} \mathrm{NOOO}^{-}+\mathrm{NO}$

$\mathrm{R}_{1} \mathrm{R}_{2} \mathrm{NH}+\mathrm{R}_{1} \mathrm{R}_{2} \mathrm{NH}^{+} \mathrm{NOOO}^{-} \leftrightarrow \mathrm{R}_{1} \mathrm{R}_{2} \mathrm{NH}_{2}^{+}+\mathrm{R}_{1} \mathrm{R}_{2} \mathrm{NNOOO}^{-}$

$\mathrm{R}_{1}, \mathrm{R}_{2}=\mathrm{H}$ or $\mathrm{CH}_{2}$

In Fig. 10a, the peaks at $1525 \mathrm{~cm}^{-1}, 1396 \mathrm{~cm}^{-1}$, and $1246 \mathrm{~cm}^{-1}$ may represent different types of $\mathrm{NO}_{2}$ stretching vibrations in $\mathrm{N}$-nitro compounds $\left(\mathrm{N}-\mathrm{NO}_{2}\right)[22,63]$. Corresponding peaks are observed at $1525 \mathrm{~cm}^{-1}, 1400 \mathrm{~cm}^{-1}$, and
$1242 \mathrm{~cm}^{-1}$ in Fig. 10b. Meanwhile, the peak at $962 \mathrm{~cm}^{-1}$ in Fig. 10a and the peak at $957 \mathrm{~cm}^{-1}$ in Fig. 10b may represent the $\mathrm{N}-\mathrm{N}$ stretching vibration in $\mathrm{N}$-nitro compounds [63]. Moreover, in Fig. 10a, the two peaks at $1525 \mathrm{~cm}^{-1}$ and $1396 \mathrm{~cm}^{-1}$ may also represent $\mathrm{NO}_{2}$ asymmetric and symmetric stretching vibrations in C-nitro compounds $\left(\mathrm{C}-\mathrm{NO}_{2}\right)$ [63]. The peak at $1377 \mathrm{~cm}^{-1}$ may represent the $\mathrm{N}=\mathrm{O}$ stretching vibration in C-nitroso compounds (C-NO) [63], with the $\mathrm{C}$-nitro and $\mathrm{C}$-nitroso compounds arising due to the oxidation of $\mathrm{NO}_{2}$ to a primary amine in BPEI. $\mathrm{N}_{2} \mathrm{O}_{4}$ may also act as an oxidizing agent.

The peaks at $1680 \mathrm{~cm}^{-1}$ in Fig. $10 \mathrm{a}$ and $1676 \mathrm{~cm}^{-1}$ in Fig. 10b were observed after regeneration. The two peaks are most likely due to the $\mathrm{C}=\mathrm{O}$ stretching vibration in urea linkages. These two peaks were mutually corroborative with the two peaks at $1666 \mathrm{~cm}^{-1}$ in Fig. 9a and b. Therefore, similar to $\mathrm{SO}_{2}, \mathrm{NO}_{2}$ also promotes the formation of urea linkages between $\mathrm{PEI}$ functional adsorbents and $\mathrm{CO}_{2}$.

At $3215 \mathrm{~cm}^{-1}$ in Fig. 10a and $3190 \mathrm{~cm}^{-1}$ in Fig. 10b, apparent variations are observed. These two peaks gradually strengthened and can be observed after regeneration. A similar observation was noted at $3224 \mathrm{~cm}^{-1}$ in Fig. $7 \mathrm{a}$. These peaks most likely represent the $\mathrm{O}-\mathrm{H}$ vibration in acid. We hypothesized that the following Eqs. (10) to (15) might explain the appearance of the peak:

$\mathrm{RNH}_{2}+\mathrm{CO}_{2} \leftrightarrow \mathrm{RNH}_{2}^{+} \mathrm{COO}^{-} \leftrightarrow \mathrm{RHNCOOH}$

$\mathrm{RNH}_{2}+\mathrm{SO}_{2} \leftrightarrow \mathrm{RNH}_{2}^{+} \mathrm{SOO}^{-} \leftrightarrow \mathrm{RHNSOOH}$ 

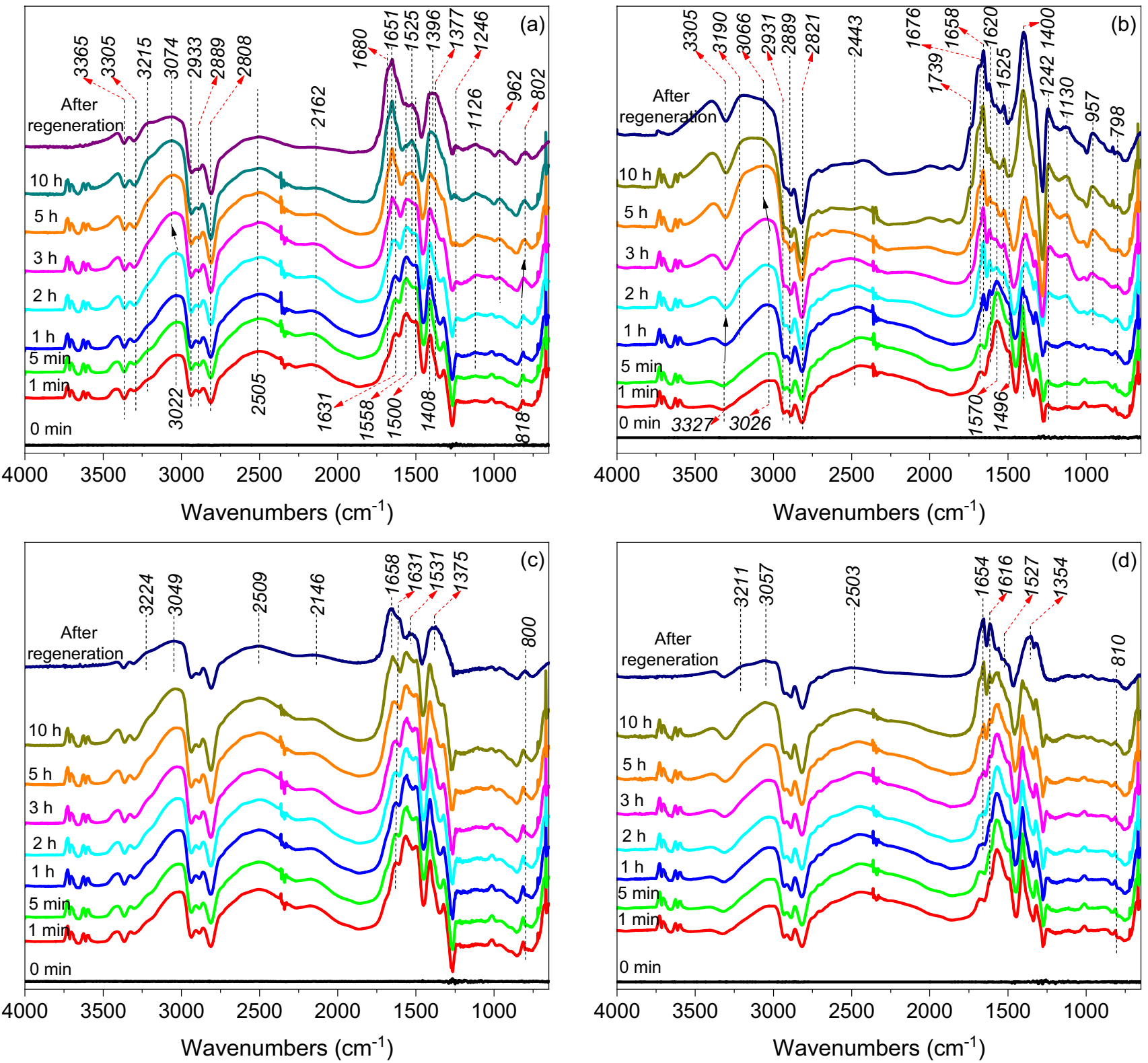

Fig. 10 In situ DRIFT spectra of a BPEI-SiO ${ }_{2}$ and $\mathbf{b} \mathrm{LPEI}_{-} \mathrm{SiO}_{2}$ when interacting with 200 ppm $\mathrm{NO}_{2}\left(15 \% \mathrm{CO}_{2}\right.$ and 200 ppm $\mathrm{NO}_{2}$ balanced with $\mathrm{N}_{2}$ ) and of $\mathbf{c ~ B P E I - S i O}$ and (d) $\mathrm{LPEI}_{2} \mathrm{SiO}_{2}$ when interacting with $10 \mathrm{ppm} \mathrm{NO} \mathrm{NO}_{2}\left(15 \% \mathrm{CO}_{2}\right.$ and $10 \mathrm{ppm} \mathrm{NO}$ balanced with $\left.\mathrm{N}_{2}\right)$

$\mathrm{R}_{1} \mathrm{R}_{2} \mathrm{NH}+\mathrm{NO}_{2} \leftrightarrow \mathrm{R}_{1} \mathrm{R}_{2} \mathrm{NH}^{+} \mathrm{NOO}^{-} \leftrightarrow \mathrm{R}_{1} \mathrm{R}_{2} \mathrm{NNOOH}$

$\mathrm{NO}_{2}+\mathrm{NO}_{2} \leftrightarrow \mathrm{N}_{2} \mathrm{O}_{4}$

$\mathrm{R}_{1} \mathrm{R}_{2} \mathrm{NH}_{2}+\mathrm{N}_{2} \mathrm{O}_{4} \leftrightarrow \mathrm{R}_{1} \mathrm{R}_{2} \mathrm{NH}^{+} \mathrm{NOOO}^{-}+\mathrm{NO}$

$\mathrm{R}_{1} \mathrm{R}_{2} \mathrm{NH}^{+} \mathrm{NOOO}^{-} \leftrightarrow \mathrm{R}_{1} \mathrm{R}_{2} \mathrm{NNOOOH}$

$\mathrm{R}_{1}, \mathrm{R}_{2}=\mathrm{H}$ or $\mathrm{CH}_{2}$
Figure $10 \mathrm{c}$ and $\mathrm{d}$ show in situ DRIFT spectra during interaction with $10 \mathrm{ppm} \mathrm{NO} \mathrm{NO}_{2}\left(15 \% \mathrm{CO}_{2}\right.$ and $10 \mathrm{ppm} \mathrm{NO}$ balanced with $\mathrm{N}_{2}$ ) for BPEI-SiO ${ }_{2}$ and $\mathrm{LPEI}-\mathrm{SiO}_{2}$. The spectra are similar to those in Fig. 10a and b, but with a much weaker absorption intensity. Therefore, $10 \mathrm{ppm} \mathrm{NO} \mathrm{N}_{2}$ could also lead to degradation of $\mathrm{BPEI}-\mathrm{SiO}_{2}$ and $\mathrm{LPEI}-\mathrm{SiO}_{2}$ via similar mechanisms. The degradation induced by $10 \mathrm{ppm} \mathrm{NO}$ was very slight, and therefore no pronounced decrease in the $\mathrm{CO}_{2}$ adsorption capacity was observed. However, when the $\mathrm{CO}_{2}$ cyclic adsorption-desorption cycles were increased, both $\mathrm{BPEI}-\mathrm{SiO}_{2}$ and $\mathrm{LPEI}^{-\mathrm{SiO}_{2}}$ encountered a 
loss in their $\mathrm{CO}_{2}$ adsorption capacity under the $10 \mathrm{ppm}$ $\mathrm{NO}_{2}$ scenario

\subsection{The adverse effects of NO}

As mentioned above, NO typically accounts for over $95 \%$ of the total $\mathrm{NO}_{\mathrm{x}}$ in flue gas. We only investigated the impact of $200 \mathrm{ppm} \mathrm{NO}$ on BPEI-SiO ${ }_{2}$ and $\mathrm{LPEI}^{-\mathrm{SiO}_{2}}$. Figure $11 \mathrm{a}$ and $\mathrm{b}$ show the changes in the $\mathrm{CO}_{2}$ adsorption capacity of $\mathrm{BPEI}-\mathrm{SiO}_{2}$ and $\mathrm{LPEI}-\mathrm{SiO}_{2}$ after exposure to $200 \mathrm{ppm} \mathrm{NO}$ $\left(15 \% \mathrm{CO}_{2}\right.$ and $200 \mathrm{ppm}$ NO balanced with $\mathrm{N}_{2}$ ). The $\mathrm{CO}_{2}$ adsorption performance of $\mathrm{BPEI}-\mathrm{SiO}_{2}$ and $\mathrm{LPEI}-\mathrm{SiO}_{2}$ was very stable during the whole process.

In Fig. 12a and b, the DRIFT spectrum of BPEI$\mathrm{SiO}_{2}(200 \mathrm{ppm} \mathrm{NO})$ is similar to that of $\mathrm{BPEI}^{-\mathrm{SiO}_{2}}(15 \%$ $\mathrm{CO}_{2}$ ), while the DRIFT spectrum of $\mathrm{LPEI}^{-\mathrm{SiO}_{2}}(200 \mathrm{ppm} \mathrm{NO})$ is similar to that of $\mathrm{LPEI}-\mathrm{SiO}_{2}\left(15 \% \mathrm{CO}_{2}\right)$. Compared with the DRIFT spectra of $\mathrm{BPEI}_{-} \mathrm{SiO}_{2}$, the absorption intensity of the peak at approximately $1666 \mathrm{~cm}^{-1}$ was stronger in the DRIFT spectra of BPEI-SiO $2(200 \mathrm{ppm} \mathrm{NO})$ and BPEI$\mathrm{SiO}_{2}\left(15 \% \mathrm{CO}_{2}\right)$. The sharp peak at $1558 \mathrm{~cm}^{-1}$ was far more prominent for $\mathrm{LPEI}-\mathrm{SiO}_{2}(200 \mathrm{ppm} \mathrm{NO})$ and $\mathrm{LPEI}^{-\mathrm{SiO}_{2}}(15 \%$ $\mathrm{CO}_{2}$ ) than for $\mathrm{LPEI}-\mathrm{SiO}_{2}$. These two peaks at $1666 \mathrm{~cm}^{-1}$ and $1558 \mathrm{~cm}^{-1}$ represent the $\mathrm{C}=\mathrm{O}$ stretching vibration and the $\mathrm{C}-\mathrm{N}$ stretching vibration in urea linkages. This is due mainly to the formation of urea linkages during the $\mathrm{CO}_{2}$ cyclic adsorption-desorption processes. The DRIFT spectra provide no information on the degradation induced by NO.

Figure 13a and $b$ show the in situ DRIFT spectra for BPEI$\mathrm{SiO}_{2}$ and $\mathrm{LPEI}-\mathrm{SiO}_{2}$ during interaction with $200 \mathrm{ppm} \mathrm{NO}$ $\left(15 \% \mathrm{CO}_{2}\right.$ and 200 ppm NO balanced with $\left.\mathrm{N}_{2}\right)$. No apparent changes were observed for $\mathrm{BPEI}-\mathrm{SiO}_{2}$ or $\mathrm{LPEI}-\mathrm{SiO}_{2}$ during the interaction processes. But some peaks remained after regeneration in Fig. 13a, for example, the peaks at $2985 \mathrm{~cm}^{-1}$ and $2509 \mathrm{~cm}^{-1}$ denoting the $\mathrm{NH}_{3}{ }^{+} / \mathrm{NH}_{2}{ }^{+}$vibration $[56,61,64]$, the peak at $1657 \mathrm{~cm}^{-1}$ representing the $\mathrm{N}=\mathrm{O}$ vibration [63], the peak at $1606 \mathrm{~cm}^{-1}$ most likely denoting the $\mathrm{NH}_{2}^{+}$vibration, and the peak at $1011 \mathrm{~cm}^{-1}$ likely representing the $\mathrm{N}-\mathrm{N}$ stretching vibration. All of these peaks were observed at similar locations in Fig. 13b. Equations (16) to (18), shown below, may provide an explanation for these peaks [69]. The reaction in Eq. (16) limited the formation of $\mathrm{R}_{1} \mathrm{R}_{2} \mathrm{NH}_{2}{ }^{+} \mathrm{R}_{1} \mathrm{R}_{2} \mathrm{NHN}_{2} \mathrm{O}_{2}{ }^{-}$and further confined the degradation of $\mathrm{BPEI}-\mathrm{SiO}_{2}$ and $\mathrm{LPEI}-\mathrm{SiO}_{2}$ induced by NO.

$\mathrm{R}_{1} \mathrm{R}_{2} \mathrm{NH}+\mathrm{NO} \leftrightarrow \mathrm{R}_{1} \mathrm{R}_{2} \mathrm{NHNO}$ (slow)

$\mathrm{R}_{1} \mathrm{R}_{2} \mathrm{NHNO}+\mathrm{NO} \leftrightarrow \mathrm{R}_{1} \mathrm{R}_{2} \mathrm{NHN}_{2} \mathrm{O}_{2}$ (fast)

$\mathrm{R}_{1} \mathrm{R}_{2} \mathrm{NHN}_{2} \mathrm{O}_{2}+\mathrm{R}_{1} \mathrm{R}_{2} \mathrm{NH} \leftrightarrow \mathrm{R}_{1} \mathrm{R}_{2} \mathrm{NH}_{2}^{+} \mathrm{R}_{1} \mathrm{R}_{2} \mathrm{NHN}_{2} \mathrm{O}_{2}^{-}$(fast)

$\mathrm{R}_{1}, \mathrm{R}_{2}=\mathrm{H}$ or $\mathrm{CH}_{2}$

Furthermore, the peak at $1361 \mathrm{~cm}^{-1}$ in Fig. $13 \mathrm{a}$ and the peak at $1360 \mathrm{~cm}^{-1}$ in Fig. $13 \mathrm{~b}$ may be associated with the formation of $\mathrm{N}$-nitroso compounds $(\mathrm{N}-\mathrm{N}=\mathrm{O})[71,72]$. These results demonstrate that $\mathrm{NO}$ can lead to degradation of PEl functional adsorbents by forming $\mathrm{R}_{1} \mathrm{R}_{2} \mathrm{NH}_{2}{ }^{+}$ $\mathrm{R}_{1} \mathrm{R}_{2} \mathrm{NHN}_{2} \mathrm{O}_{2}{ }^{-}$and $\mathrm{N}$-nitroso compounds. However, the degradation induced by NO was extremely low and
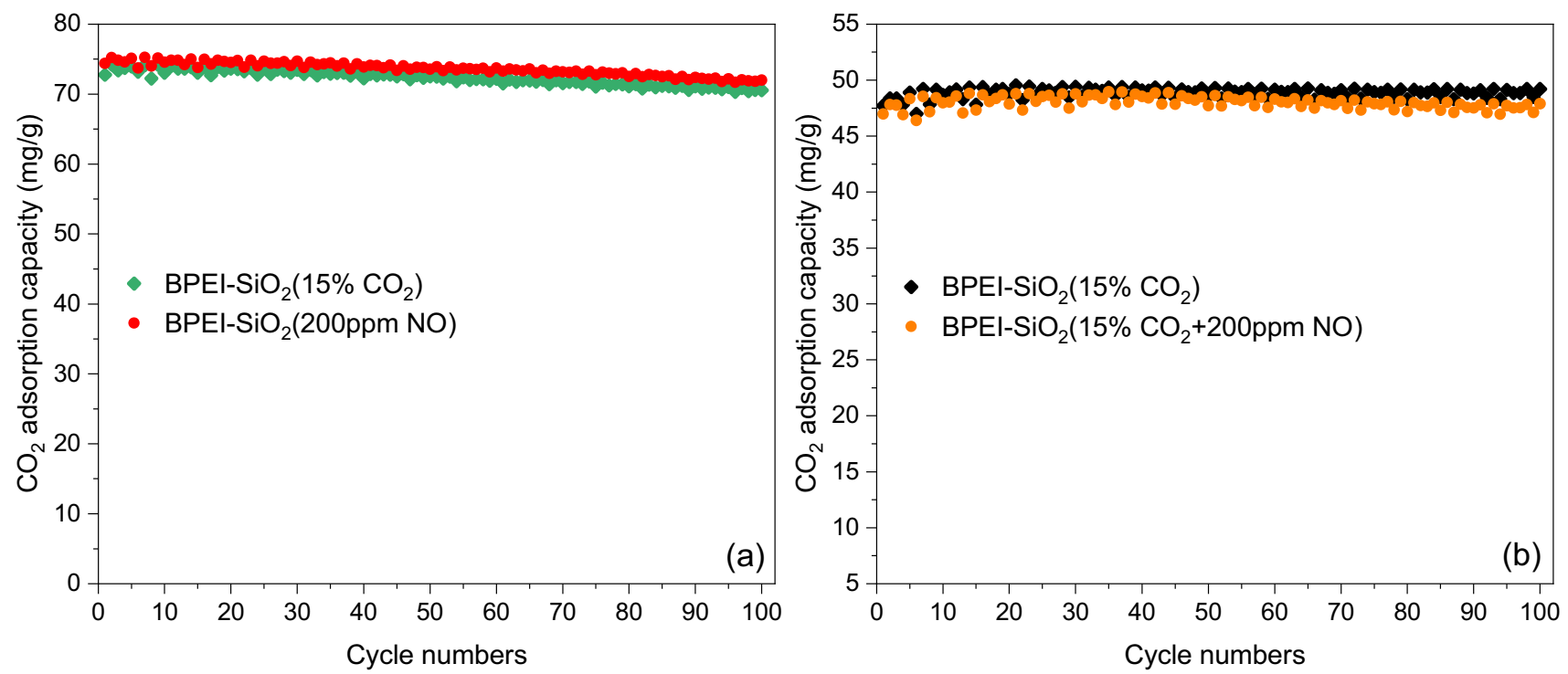

Fig. $11 \mathrm{CO}_{2}$ cyclic adsorption-desorption results for a BPEI-SiO ${ }_{2}\left(15 \% \mathrm{CO}_{2}\right)$ and $\mathrm{BPEI}-\mathrm{SiO}_{2}(200 \mathrm{ppm} \mathrm{NO})$ and $\mathbf{b} \mathrm{LPEI}_{-} \mathrm{SiO}_{2}\left(15 \% \mathrm{CO}_{2}\right)$ and LPEI$\mathrm{SiO}_{2}(200$ ppm NO) 

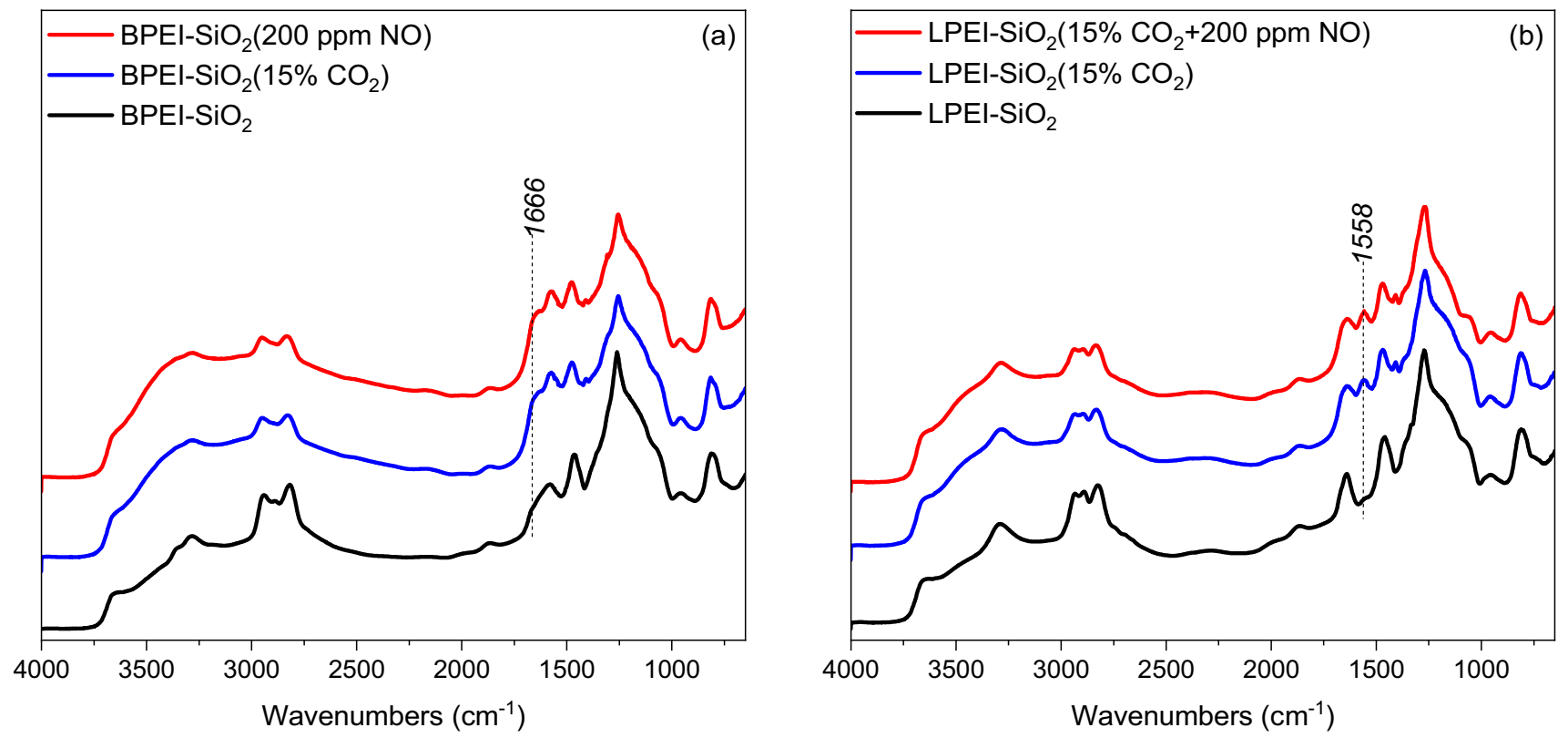

Fig. 12 DRIFT spectra of a BPEI-SiO ${ }_{2}, \mathrm{BPEI}_{-} \mathrm{SiO}_{2}\left(15 \% \mathrm{CO}_{2}\right)$, and $\mathrm{BPEI}_{-} \mathrm{SiO}_{2}(200 \mathrm{ppm} \mathrm{NO})$ and $\mathbf{b} \mathrm{LPEI}_{-} \mathrm{SiO}_{2}, \mathrm{LPEI}_{-} \mathrm{SiO}_{2}\left(15 \% \mathrm{CO}_{2}\right)$, and LPEI$\mathrm{SiO}_{2}(200 \mathrm{ppm} \mathrm{NO})$
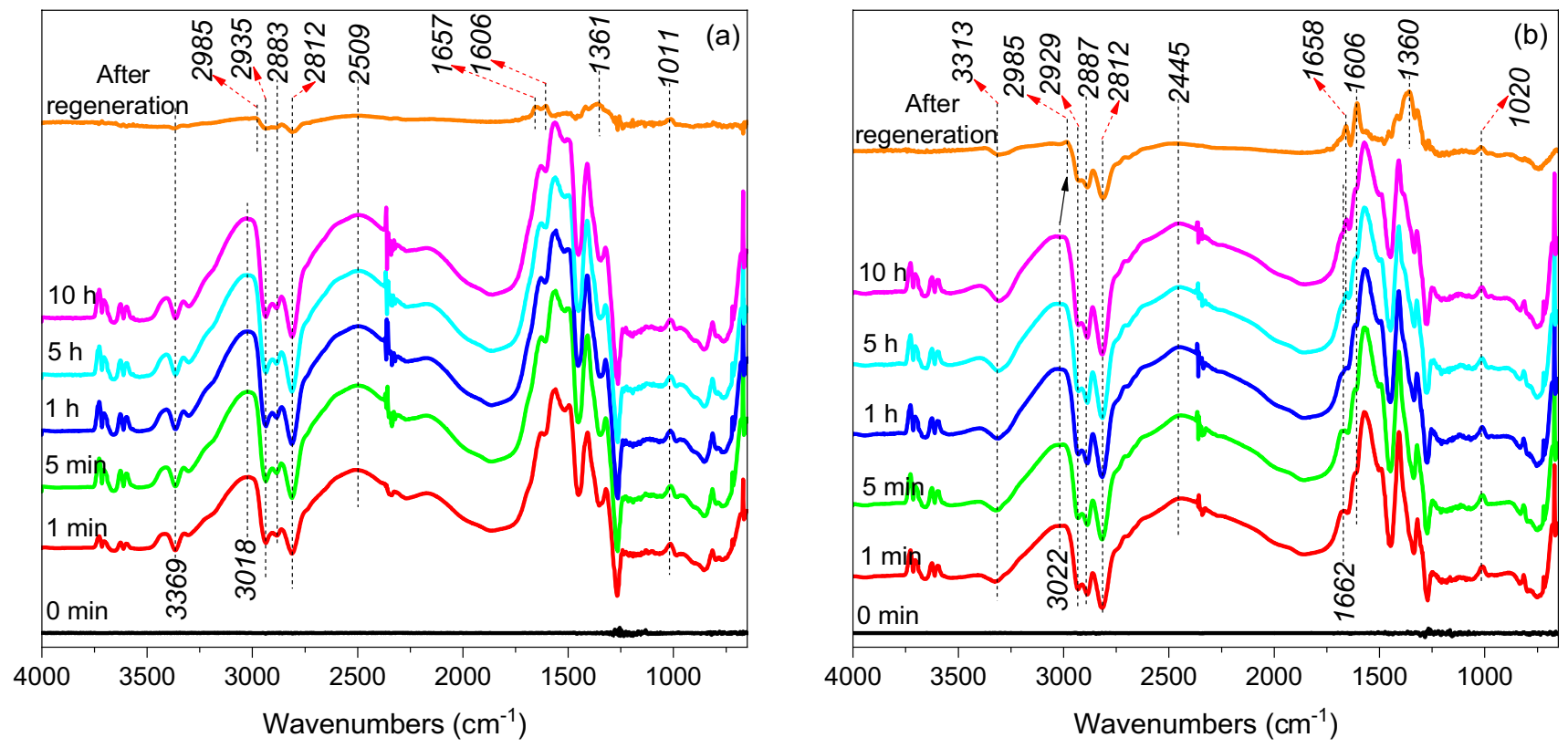

Fig. 13 In situ DRIFT spectra of a $\mathrm{BPEI}_{-} \mathrm{SiO}_{2}$, and $\mathbf{b} \mathrm{LPEI}_{-} \mathrm{SiO}_{2}$ during interaction with $200 \mathrm{ppm} \mathrm{NO}\left(15 \% \mathrm{CO}_{2}\right.$ and 200 ppm NO balanced with $\mathrm{N}_{2}$ )

would not cause an obvious decrease in the $\mathrm{CO}_{2}$ adsorption capacity during the limited duration of $\mathrm{CO}_{2}$ cyclic adsorption-desorption tests.

\section{Conclusions}

In this study, the adverse effects of simulated flue gas on BPEI and LPEI functional adsorbents were investigated. 
The results showed that $\mathrm{O}_{2}, \mathrm{SO}_{2}, \mathrm{NO}_{2}$, and $\mathrm{NO}$ all caused degradation of PEl functional adsorbents. After contact with $10 \% \mathrm{O}_{2}\left(15 \% \mathrm{CO}_{2}\right.$ and $10 \% \mathrm{O}_{2}$ in $\left.\mathrm{N}_{2}\right)$ for 990 cumulative minutes, $\mathrm{BPEI}-\mathrm{SiO}_{2}$ lost $23.0 \%$ of its original $\mathrm{CO}_{2}$ adsorption capacity. On the other hand, $\mathrm{LPEI}-\mathrm{SiO}_{2}$ maintained a stable $\mathrm{CO}_{2}$ adsorption performance during the adsorption process and only lost approximately $3.6 \%$ of its original adsorption capacity. However, the IR spectra demonstrated that $10 \% \mathrm{O}_{2}$ also damages LPEI$\mathrm{SiO}_{2}$. Three concentration gradients were considered for $\mathrm{SO}_{2}$, namely 10,50 , and 200 ppm SO $2\left(15 \% \mathrm{CO}_{2}\right.$ and 10,50 , or $200 \mathrm{ppm} \mathrm{SO} \mathrm{S}_{2}$ in $\mathrm{N}_{2}$ ). Higher concentrations of $\mathrm{SO}_{2}$ would lead to more severe and quicker degradation of $\mathrm{BPEI}-\mathrm{SiO}_{2}$ and $\mathrm{LPEI}-\mathrm{SiO}_{2}$. After contact with 10,50 , or 200 ppm SO${ }_{2}$ for 990 cumulative minutes, $\mathrm{BPEI}_{-} \mathrm{SiO}_{2}$ lost $18.2 \%, 61.4 \%$, and $89.0 \%$ of its original $\mathrm{CO}_{2}$ adsorption capacity, and $\mathrm{LPEI}-\mathrm{SiO}_{2}$ lost $18.5 \%, 60.6 \%$, and $78.5 \%$ of its original $\mathrm{CO}_{2}$ adsorption capacity, respectively. As for $\mathrm{NO}_{x}, 10 \mathrm{ppm} \mathrm{NO} \mathrm{N}_{2}\left(15 \% \mathrm{CO}_{2}\right.$ and $10 \mathrm{ppm} \mathrm{NO} \mathrm{N}_{2}$ in $\left.\mathrm{N}_{2}\right)$ and $200 \mathrm{ppm} \mathrm{NO}\left(15 \% \mathrm{CO}_{2}\right.$ and $200 \mathrm{ppm} \mathrm{NO}$ in $\mathrm{N}_{2}$ ) caused almost no decrease in the $\mathrm{CO}_{2}$ adsorption capacity after 990-min interactions, but as shown by the IR spectra, both concentrations induced degradation of $\mathrm{BPEI}^{-\mathrm{SiO}_{2}}$ and $\mathrm{LPEI}_{-} \mathrm{SiO}_{2}$. We also investigated $200 \mathrm{ppm} \mathrm{NO} 2$ (15\% $\mathrm{CO}_{2}$ and $200 \mathrm{ppm} \mathrm{NO} \mathrm{N}_{2}$ in $\mathrm{N}_{2}$ ) and observed a $49.6 \%$ and $49.5 \%$ decrease in the original $\mathrm{CO}_{2}$ adsorption capacity of $\mathrm{BPEI}_{-} \mathrm{SiO}_{2}$ and $\mathrm{LPEI}-\mathrm{SiO}_{2}$, respectively.

Further exploration of the degradation mechanism demonstrated that $\mathrm{O}_{2}$ oxidized the $-\mathrm{CH}_{2}$ and $-\mathrm{CH}_{2}-\mathrm{NH}$ - groups of $\mathrm{BPEI}-\mathrm{SiO}_{2}$ to form $\mathrm{C}=\mathrm{O}$ and $\mathrm{C}=\mathrm{N}$ groups, and $\mathrm{C}=\mathrm{O}$ formation seems to be the primary pathway. For $\mathrm{LPEI}^{-\mathrm{SiO}_{2}}$, only $\mathrm{C}=\mathrm{O}$ formation via oxidation of $-\mathrm{CH}_{2}$ - was observed. $\mathrm{SO}_{2}$ can react with the amine groups of $\mathrm{BPEl}-\mathrm{SiO}_{2}$ and $\mathrm{LPEI}-\mathrm{SiO}_{2}$ to form heat-stable $\mathrm{NH}_{3}{ }^{+}$-and/ or $\mathrm{NH}_{2}^{+}$- containing adducts. $\mathrm{SO}_{2}$ can promote the formation of urea linkages between PEI functional adsorbents and $\mathrm{CO}_{2}$. Similar to $\mathrm{SO}_{2}$, the presence of $\mathrm{NO}_{2}$ can lead to the formation of heat-stable $\mathrm{NH}_{3}{ }^{+}$-and/or $\mathrm{NH}_{2}{ }^{+}$- containing adducts and promote urea linkage formation. Furthermore, $\mathrm{NO}_{2}$ can result in the formation of heatstable acid adducts and, likely, $\mathrm{N}$-nitro $\left(\mathrm{N}-\mathrm{NO}_{2}\right), \mathrm{C}$-nitroso $(\mathrm{C}-\mathrm{N}=\mathrm{O})$, and $\mathrm{C}$-nitro $\left(\mathrm{C}-\mathrm{NO}_{2}\right)$ compounds. $\mathrm{NO}$ can lead to the formation of heat-stable $\mathrm{NH}_{3}{ }^{+}$-and/or $\mathrm{NH}_{2}{ }^{+}$- containing adducts, as well as $\mathrm{N}$-nitroso $(\mathrm{N}-\mathrm{N}=\mathrm{O})$ compounds.

\section{Supplementary Information}

Molecular structures of BPEl and LPEI are shown in Scheme $\mathrm{S} 1$. Detailed in situ DRIFT spectra of $\mathrm{BPEI}^{-\mathrm{SiO}_{2}}$ and LPEI$\mathrm{SiO}_{2}$ during interaction with different gas mixtures are shown in Figure $\mathrm{S} 1$ to $\mathrm{S} 15$.
Acknowledgements The authors are really grateful for the supports of the Postdoctoral Fellowship Scheme of The Hong Kong Polytechnic University (Scheme No. G-YW3U). And the authors sincerely acknowledge the supports from Shanghai Tongji Gao Tingyao Environmental Science \& Technology Development Foundation.

\section{Compliance with ethical standards}

Conflict of interest The authors declare that there is no any competing interest.The English in this document has been checked by at least two professional editors, both native speakers of English. For a certificate, please see: http://www.textcheck.com/certificate/HjvYgi

Open Access This article is licensed under a Creative Commons Attribution 4.0 International License, which permits use, sharing, adaptation, distribution and reproduction in any medium or format, as long as you give appropriate credit to the original author(s) and the source, provide a link to the Creative Commons licence, and indicate if changes were made. The images or other third party material in this article are included in the article's Creative Commons licence, unless indicated otherwise in a credit line to the material. If material is not included in the article's Creative Commons licence and your intended use is not permitted by statutory regulation or exceeds the permitted use, you will need to obtain permission directly from the copyright holder. To view a copy of this licence, visit http://creativecommons .org/licenses/by/4.0/.

\section{References}

1. International Engergy Agency, Energy Technology Perspectives (2020 https://www.iea.org/reports/energy-technology-persp ectives-2020. September 2020.

2. Murge P, Dinda S, Roy S (2019) Zeolite-based sorbent for $\mathrm{CO}_{2}$ capture: preparation and performance evaluation. Langmuir 35(46):14751-14760

3. Megias-Sayago C, Bingre R, Huang L, Lutzweiler G, Wang Q, Louis $\mathrm{B}$ (2019) $\mathrm{CO}_{2}$ Adsorption capacities in zeolites and layered double hydroxide materials. Fron Chem 7:551

4. You YY, Liu XJ (2019) Modeling of $\mathrm{CO}_{2}$ adsorption and recovery from wet flue gas by using activated carbon. Chem Eng J 369:672-685

5. Gunawan T, Wijiyanti R, Widiastuti N (2018) Adsorption-desorption of $\mathrm{CO}_{2}$ on zeolite-Y-templated carbon at various temperatures. RSC Adv 8(72):41594-41602

6. Tan P, Jiang Y, Liu X, Sun LB (2019) Making porous materials respond to visible light. ACS Energy Lett 4(11):2656-2667

7. Hu Z, Wang Y, Shah BB, Zhao D (2019) CO2 capture in metalorganic framework adsorbents: an engineering perspective. Adv Sustain Syst 3(1):1800080

8. Perejon A, Romeo LM, Lara Y, Lisbona P, Martinez A, Valverde JM (2016) The Calcium-Looping technology for $\mathrm{CO}_{2}$ capture: On the important roles of energy integration and sorbent behavior. Appl Energy 162:787-807

9. Arias $\mathrm{B}$, Alonso $\mathrm{M}$, Abanades $\mathrm{C}$ (2017) $\mathrm{CO}_{2}$ Capture by calcium looping at relevant conditions for cement plants: experimental testing in a $30 \mathrm{~kW}$ (th) pilot plant. Ind Eng Chem Res 56(10):2634-2640

10. Jiang Y, Tan P, Qi SC, Liu XQ, Yan JH, Fan F, Sun LB (2019) Metalorganic frameworks with target-specific active sites switched by photoresponsive motifs: efficient adsorbents for tailorable $\mathrm{CO}_{2}$ capture. Angew Chem-Int Edn 58(20):6600-6604

11. Jiang Y, Shi XC, Tan P, Qi SC, Gu C, Yang T, Peng SS, Liu XQ, Sun LB (2020) Controllable $\mathrm{CO}_{2}$ capture in metal-organic frameworks: 
making targeted active sites respond to light. Ind Eng Chem Res 59(50):21894-21900

12. Bos MJ, Kroeze V, Sutanto S, Brilman DWF (2018) Evaluating regeneration options of solid amine sorbent for $\mathrm{CO}_{2}$ removal. Ind Eng Chem Res 57(32):11141-11153

13. Li KM, Jiang JG, Chen XJ, Gao YC, Yan F, Tian SC (2016) Research on urea linkages formation of amine functional adsorbents during $\mathrm{CO}_{2}$ capture process: two key factors analysis, temperature and moisture. J Phys Chem C 120(45):25892-25902

14. Goeppert A, Meth S, Prakash GKS, Olah GA (2010) Nanostructured silica as a support for regenerable high-capacity organoamine-based $\mathrm{CO}_{2}$ sorbents. Energ Environ Sci 3(12):1949-1960

15. Didas SA, Zhu RS, Brunelli NA, Sholl DS, Jones CW (2014) Thermal, oxidative and $\mathrm{CO}_{2}$ induced degradation of primary amines used for $\mathrm{CO}_{2}$ capture: effect of alkyl linker on stability. J Phys Chem C 118(23):12302-12311

16. Sjostrom S, Krutka $H$ (2010) Evaluation of solid sorbents as a retrofit technology for $\mathrm{CO}_{2}$ capture. Fuel 89(6):1298-1306

17. Khatri RA, Chuang SSC, Soong Y, Gray M (2006) Thermal and chemical stability of regenerable solid amine sorbent for $\mathrm{CO}_{2}$ capture. Energy Fuels 20(4):1514-1520

18. Anderson JL, Dixon JK, Maginn EJ, Brennecke JF (2006) Measurement of $\mathrm{SO}_{2}$ solubility in ionic liquids. J Phys Chem B 110(31):15059-15062

19. Stevens L, Williams K, Han WY, Drage T, Snape C, Wood J, Wang JW (2013) Preparation and $\mathrm{CO}_{2}$ adsorption of diamine modified montmorillonite via exfoliation grafting route. Chem Eng J 215:699-708

20. Uyanga IJ, Idem $\mathrm{RO}$ (2007) Studies of $\mathrm{SO}_{2}$ - and $\mathrm{O}_{2}$-induced degradation of aqueous MEA during $\mathrm{CO}_{2}$ capture from power plant flue gas streams. Ind Eng Chem Res 46(8):2558-2566

21. Bollini P, Choi S, Drese JH, Jones CW (2011) Oxidative degradation of aminosilica adsorbents relevant to postcombustion $\mathrm{CO}_{2}$ capture. Energy Fuels 25(5):2416-2425

22. Miller DD, Chuang SSC (2015) Experimental and theoretical investigation of $\mathrm{SO}_{2}$ adsorption over the 1,3-phenylenediamine/ $\mathrm{SiO}_{2}$ system. J Phys Chem C 119(12):6713-6727

23. Rao AB, Rubin ES (2002) A technical, economic, and environmental assessment of amine-based $\mathrm{CO}_{2}$ capture technology for power plant greenhouse gas control. Environ Sci Technol 36(20):4467-4475

24. Lin KYA, Petit C, Park AHA (2013) Effect of $\mathrm{SO}_{2}$ on $\mathrm{CO}_{2}$ capture using liquid-like nanoparticle organic hybrid materials. Energy Fuels 27(8):4167-4174

25. Su FS, Lu CS, Chen HS (2011) Adsorption, desorption, and thermodynamic studies of $\mathrm{CO}_{2}$ with high-amine-loaded multiwalled carbon nanotubes. Langmuir 27(13):8090-8098

26. Schreiber A, Zapp P, Kuckshinrichs W (2009) Environmental assessment of German electricity generation from coal-fired power plants with amine-based carbon capture. Int J Life Cycle Assess 14(6):547-559

27. Liu YM, Ye Q, Shen M, Shi JJ, Chen J, Pan H, Shi Y (2011) Carbon Dioxide capture by functionalized solid amine sorbents with simulated flue gas conditions. Environ Sci Technol 45(13):5710-5716

28. Fan YF, Labreche Y, Lively RP, Jones CW, Koros WJ (2014) Dynamic $\mathrm{CO}_{2}$ adsorption performance of internally cooled silica-supported poly(ethylenimine) hollow fiber sorbents. Aiche J 60(11):3878-3887

29. Hallenbeck AP, Kitchin JR (2013) Effects of $\mathrm{O}_{2}$ and $\mathrm{SO}_{2}$ on the capture capacity of a primary-amine based polymeric $\mathrm{CO}_{2}$ sorbent. Ind Eng Chem Res 52(31):10788-10794

30. Chandan PA, Remias JE, Liu KL (2014) Possible ways to minimize nitrosation reactions during post-combustion $\mathrm{CO}_{2}$ capture process. Int J Greenh Gas Con 31:61-66
31. Liu YM, Lin XY, Wu XH, Liu MY, Shi RH, Yu XJ (2017) Pentaethylenehexamine loaded SBA-16 for $\mathrm{CO}_{2}$ capture from simulated flue gas. Powder Technol 318:186-192

32. Yang J, Yu XH, Yan JY, Tu ST, Dahlquist E (2013) Effects of $\mathrm{SO}_{2}$ on $\mathrm{CO}_{2}$ capture using a hollow fiber membrane contactor. Appl Energy 112:755-764

33. Wang ZM, Mitch WA (2015) Influence of dissolved metals on n-nitrosamine formation under amine-based $\mathrm{CO}_{2}$ capture conditions. Environ Sci Technol 49(19):11974-11981

34. Gouedard C, Picq D, Launay F, Carrette PL (2012) Amine degradation in $\mathrm{CO}_{2}$ capture I. a review. Int J Greenh Gas Con 10:244-270

35. Chi S, Rochelle GT (2002) Oxidative degradation of monoethanolamine. Ind Eng Chem Res 41(17):4178-4186

36. Dickinson J, Percy A, Puxty G, Verheyen TV (2016) Oxidative degradation of amine absorbents in carbon capture systems-a dynamic modelling approach. Int J Greenh Gas Con 53:391-400

37. Ahmadalinezhad A, Sayari A (2014) Oxidative degradation of silica-supported polyethylenimine for $\mathrm{CO}_{2}$ adsorption: insights into the nature of deactivated species. Phys Chem Chem Phys 16(4):1529-1535

38. Bali S, Chen TT, Chaikittisilp W, Jones CW (2013) Oxidative stability of amino polymer-alumina hybrid adsorbents for carbon dioxide capture. Energy Fuels 27(3):1547-1554

39. Wang DX, Wang XX, Song CS (2017) Comparative study of molecular basket sorbents consisting of polyallylamine and polyethylenimine functionalized SBA-15 for $\mathrm{CO}_{2}$ capture from flue gas. ChemPhysChem 18(22):3163-3173

40. Qian Y, Delgado JDLP, Veneman R, Brilman DWF (2017) Stability of a benzyl amine based $\mathrm{CO}_{2}$ capture adsorbent in view of regeneration strategies. Ind Eng Chem Res 56(12):3259-3269

41. Srikanth CS, Chuang SSC (2012) Spectroscopic investigation into oxidative degradation of silica-supported amine sorbents for $\mathrm{CO}_{2}$ capture. Chemsuschem 5(8):1435-1442

42. Gebald C, Wurzbacher JA, Tingaut $P$, Steinfeld A (2013) Stability of amine-functionalized cellulose during temperature-vacuum-swing cycling for $\mathrm{CO}_{2}$ capture from air. Environ Sci Technol 47(17):10063-10070

43. Calleja G, Sanz R, Arencibia A, Sanz-Perez ES (2011) Influence of drying conditions on amine-functionalized SBA-15 as adsorbent of $\mathrm{CO}_{2}$. Top Catal 54(1-4):135-145

44. Fan YF, Rezaei F, Labreche Y, Lively RP, Koros WJ, Jones CW (2015) Stability of amine-based hollow fiber $\mathrm{CO}_{2}$ adsorbents in the presence of $\mathrm{NO}$ and $\mathrm{SO}_{2}$. Fuel 160:153-164

45. Wu DZ, Sun CH, Dutta PK, Ho WSW (2017) $\mathrm{SO}_{2}$ interference on separation performance of amine-containing facilitated transport membranes for $\mathrm{CO}_{2}$ capture from flue gas. J Membr Sci 534:33-45

46. Rezaei F, Jones CW (2013) Stability of supported amine adsorbents to $\mathrm{SO}_{2}$ and $\mathrm{NO}_{x}$ in postcombustion $\mathrm{CO} 2$ capture 1. Single-component adsorption. Ind. Eng. Chem. Res. 52(34):12192-12201

47. Wang P, Guo YF, Zhao CW, Yan JJ, Lu P (2017) Biomass derived wood ash with amine modification for post-combustion $\mathrm{CO}_{2}$ capture. Appl Energy 201:34-44

48. Rezaei F, Jones CW (2014) Stability of supported amine adsorbents to $\mathrm{SO}_{2}$ and $\mathrm{NO}_{x}$ in postcombustion $\mathrm{CO}_{2}$ capture .2. Multicomponent adsorption. Ind. Eng. Chem. Res. 53(30):12103-12110

49. Liu Q, Xiong BT, Shi JJ, Tao MN, He Y, Shi Y (2014) Enhanced tolerance to flue gas contaminants on carbon dioxide capture using amine-functionalized multiwalled carbon nanotubes. Energy Fuels 28(10):6494-6501

50. Wang M, Yao LW, Wang JT, Zhang ZX, Qiao WM, Long DH, Ling LC (2016) Adsorption and regeneration study of polyethylenimineimpregnated millimeter-sized mesoporous carbon spheres for post-combustion $\mathrm{CO}_{2}$ capture. Appl Energy 168:282-290 
51. Chen XJ, Jiang JG, Yan F, Tian SC, Li KM (2014) A novel low temperature vapor phase hydrolysis method for the production of nano-structured silica materials using silicon tetrachloride. Rsc Adv 4(17):8703-8710

52. Srikanth CS, Chuang SSC (2013) Infrared study of strongly and weakly adsorbed $\mathrm{CO}_{2}$ on fresh and oxidatively degraded amine sorbents. J Phys Chem C 117(18):9196-9205

53. Sayari A, Belmabkhout Y, Da'na E (2012) $\mathrm{CO}_{2}$ deactivation of supported amines: does the nature of amine matter? Langmuir 28(9):4241-4247

54. Heydari-Gorji A, Sayari A (2012) Thermal, oxidative, and $\mathrm{CO}_{2}$-induced degradation of supported polyethylenimine adsorbents. Ind Eng Chem Res 51(19):6887-6894

55. Sayari A, Heydari-Gorji A, Yang Y (2012) $\mathrm{CO}_{2}$-Induced degradation of amine-containing adsorbents: reaction products and pathways. J Am Chem Soc 134(33):13834-13842

56. Wilfong WC, Srikanth CS, Chuang SSC (2014) In situ ATR and DRIFTS studies of the nature of adsorbed $\mathrm{CO}_{2}$ on tetraethylenepentamine films. ACS Appl Mater Interfaces 6(16):13617-13626

57. Sayari A, Belmabkhout $Y$ (2010) Stabilization of amine-containing $\mathrm{CO}_{2}$ adsorbents: dramatic effect of water vapor. J Am Chem Soc 132(18):6312-6314

58. Wei L, Gao Z, Wang Y (2017) Integrated two-stage adsorption for selective removal of $\mathrm{CO}_{2}$ and $\mathrm{SO}_{2}$ by amine-functionalized SBA-15. Asia-Pac J Chem Eng 12(4):660-670

59. Kim C, Cho HS, Chang S, Cho SJ, Choi M (2016) An ethylenediamine-grafted $Y$ zeolite: a highly regenerable carbon dioxide adsorbent via temperature swing adsorption without urea formation. Energ Environ Sci 9(5):1803-1811

60. Lakard S, Herlem G, Lakard B, Fahys B (2004) Theoretical study of the vibrational spectra of polyethylenimine and polypropylenimine. J Mol Struc-Theochem 685(1-3):83-87

61. Hiyoshi N, Yogo K, Yashima T (2005) Adsorption characteristics of carbon dioxide on organically functionalized SBA-15. Micropor Mesopor Mat 84(1-3):357-365

62. Okabayashi H, Shimizu I, Nishio E, O'Connor CJ (1997) Diffuse reflectance infrared Fourier transform spectral study of the interaction of 3-aminopropyltriethoxysilane on silica gel. Behavior of amino groups on the surface. Colloid Polym Sci 275(8):744-753

63. Bio-Rad Laboratories, Inc., Informatics Division, The Sadtler Handbook of Infrared Spectra.
64. Wilfong WC, Chuang SSC (2014) Probing the adsorption/desorption of $\mathrm{CO}_{2}$ on amine sorbents by transient infrared studies of adsorbed $\mathrm{CO}_{2}$ and $\mathrm{C}_{6} \mathrm{H}_{6}$. Ind Eng Chem Res 53(11):4224-4231

65. Knofel C, Martin C, Hornebecq V, Llewellyn PL (2009) Study of carbon dioxide adsorption on mesoporous aminopropylsilane-functionalized silica and titania combining microcalorimetry and in situ infrared spectroscopy. J Phys Chem C 113(52):21726-21734

66. Wankhade PM, Gambhire AB, Muley GG (2016) Influence of urea doping on optical, thermal, mechanical and electrical properties of L-arginine phosphate monohydrate crystals for NLO applications. Optik 127(6):3322-3328

67. Tailor R, Abboud M, Sayari A (2014) Supported polytertiary amines: highly efficient and selective $\mathrm{SO}_{2}$ adsorbents. Environ Sci Technol 48(3):2025-2034

68. Tailor R, Ahmadalinezhad A, Sayari A (2014) Selective removal of $\mathrm{SO}_{2}$ over tertiary amine-containing materials. Chem Eng J 240:462-468

69. Diaf A, Garcia JL, Beckman EJ (1994) Thermally reversible polymeric sorbents for acid gases $-\mathrm{CO}_{2}, \mathrm{SO}_{2}$, and $\mathrm{NO}_{x}$. J Appl Polym Sci 53(7):857-875

70. Botheju D, Glarborg P, Tokheim LA (2012) $\mathrm{NO}_{x}$ reduction using amine reclaimer wastes (ARW) generated in post combustion $\mathrm{CO}_{2}$ capture. Int J Greenh Gas Con 10:33-45

71. Drago RS, Paulik FE (1960) The reaction of nitrogen (II) oxide with diethylamine. J Am Chem Soc 82(1):96-98

72. Diaf A, Beckman EJ (1995) Thermally reversible polymeric sorbents for acid gases, IV. affinity tuning for the selective dry sorption of NOx. React Polym 25(1):89-96

73. Dai N, Shah AD, Hu LH, Plewa MJ, McKague B, Mitch WA (2012) Measurement of nitrosamine and nitramine formation from no reactions with amines during amine-based carbon dioxide capture for postcombustion carbon sequestration. Environ Sci Technol 46(17):9793-9801

Publisher's Note Springer Nature remains neutral with regard to jurisdictional claims in published maps and institutional affiliations. 